\title{
Working
}

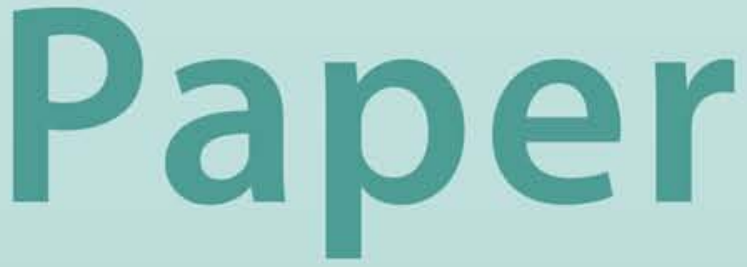




\section{Boom-Bust Phases in Asset Prices and Fiscal Policy Behavior}

Albert Jaeger and Ludger Schuknecht 


\title{
IMF Working Paper
}

\author{
European Department
}

\section{Boom-Bust Phases in Asset Prices and Fiscal Policy Behavior}

Prepared by Albert Jaeger and Ludger Schuknecht ${ }^{1}$

April 2004

\begin{abstract}
This Working Paper should not be reported as representing the views of the IMF. The views expressed in this Working Paper are those of the author(s) and do not necessarily represent those of the IMF or IMF policy. Working Papers describe research in progress by the author(s) and are published to elicit comments and to further debate.

Boom and bust phases in asset prices have become a pervasive feature of macroeconomic developments in many advanced economies. This paper studies fiscal policy during boom-bust phases in asset prices and draws several conclusions. First, expansions and contractions in economic activity during such boom-bust phases tend to be highly persistent, cyclical turning points are harder to forecast, and the margins of error for output gap estimates can be large. Second, conventional estimates of revenue elasticities seem not to allow an accurate assessment of the fiscal stance and of the strength of underlying fiscal positions during boombust phases. And third, boom-bust phases tend to exacerbate already existing procyclical policy biases, as well as political-economy biases, toward higher spending and public debt ratios.
\end{abstract}

JEL Classification Numbers: E32, E62, E63

Keywords: Boom-bust cycles, fiscal policy, asset prices, cyclical adjustment, deficit bias Author's E-Mail Address: AJaeger@imf.org and LSchuknecht@ECB.int

\footnotetext{
${ }^{1}$ International Monetary Fund and European Central Bank, respectively. The views expressed are solely our own and do not necessarily reflect those of our respective institutions. We thank Michael Deppler, Robert Flood, Eduardo Ley, Martin Mühleisen, Roberto Perotti, Axel Schimmelpfennig, participants of a seminar in the IMF's Fiscal Affairs Department, where the second author was a visiting scholar during summer 2003, participants at the EU Commission's research seminar, and the participants of an ECB seminar on fiscal and monetary policy challenges in boom-bust phases for valuable comments. We also thank Angelo Alexander and Sergei Antoshin for excellent research assistance.
} 
Contents Page

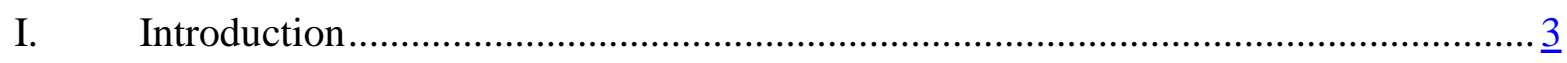

II. Identifying Boom and Bust Phases in Asset Prices .......................................... $\underline{8}$

III. Asset Price Swings and Gauging Output Developments ..................................... 12

IV. Asset Price Swings and Fiscal Developments and Policy Behavior........................ 20

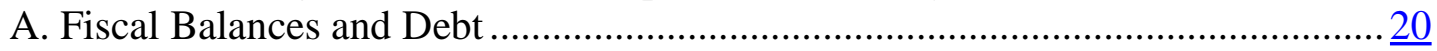

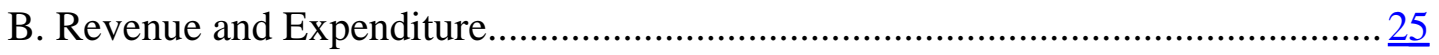

C. Measurement of Underlying Fiscal Positions .............................................. 27

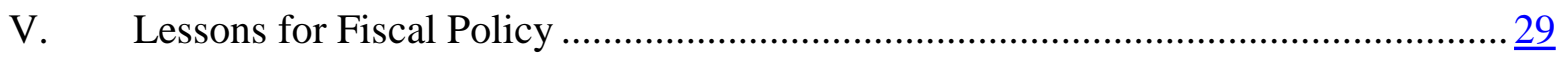

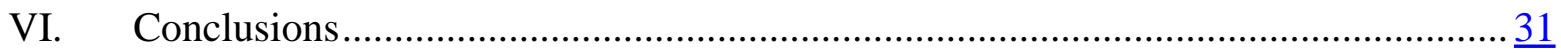

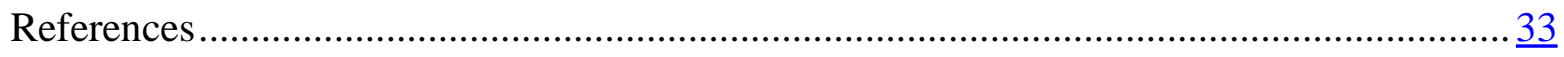

Tables

1. Characteristics of Asset Price Cycles in Industrial Countries, 1970-2002 _...............11

2. Industrial Countries: Size Distribution of Identified Boom and Bust Phases in Real Asset Prices, 1970-2002 ...................................................................... 11

3. Real GDP Growth Forecast Errors During Boom-Bust Cycles in Asset Prices ......... $\underline{16}$

4. Boom-Bust Cycles and the Macroeconomic Environment..................................... 18

5. Output Revisions and Boom-Bust Cycles......................................................... 19

6. Boom-Bust Cycles, Fiscal Balances and Public Debt ......................................... 21

7. Correlation Between Fiscal Balances and Growth in Real Output and

Asset Prices .................................................................................................

8. The Response of Fiscal Balances to Real GDP Growth During Asset Price

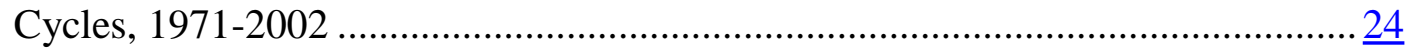

9. Boom-Bust Cycles and Revenue and Expenditure Trends ..................................... $\frac{26}{27}$

10. Revision of 1999 Cyclically Adjusted Balances, Selected EU Countries ................. $\frac{27}{28}$

11. Sweden's Fiscal Structural Balance Determinants, 1986-1993 ............................. 28

Figures

1. Asset Prices, GDP Growth, and Fiscal Balance, 1971-2002 ….............................. 4

2. Boom-Bust Phases in Asset Prices, 1970-2002 …............................................. 10

3. Real GDP Growth and Asset Price Cycles, 1971-2002 ........................................ $\frac{13}{13}$

4. Real Economic Growth in "Typical” Boom-Bust Phase ....................................... 14

5. Correlation Coefficient; Changes in Real Asset Prices and Real Output ..................14

6. Inflation and Length of Downturns During Busts ............................................ 16

7. Asset Price Cycles and Fiscal Variables ........................................................... 22 
And there were seven cows, fat and sleek coming out of the Nile ... And then seven other cows came up, behind them, starved, very wretched and lean ... The lean and wretched cows ate up the first seven fat cows. Genesis, 41.18-19

\section{INTRODUCTION}

While the above biblical quote suggests that persistent boom-bust cycles are a long-standing feature of economic life, macroeconomists' interest in such events has recently been rekindled by the unusual persistence and amplitude of asset price swings in many industrial economies since the early 1980s. This stylized fact is documented among others by Bordo and Jeanne (2002) and Detken and Smets (2003). In particular, many countries ended the 1990s on the crest of unprecedented stock market booms that subsequently turned into busts and unexpectedly persistent slowdowns in growth; more recently, several countries experienced record-setting housing price booms. The causes for the increase in amplitude and persistence of asset price cycles since the early 1980s seem to be varied, if not elusive. ${ }^{2}$ At the same time, there seems to be little dispute that large asset price swings confront policymakers with diagnostic conundrums and difficult policy choices.

This paper focuses on the behavior of fiscal policy during boom-bust phases in asset prices. While the literature on the appropriate conduct of monetary policy in a boom-bust cycle setting is already voluminous, and expanding at a rapid clip, ${ }^{3}$ the parallel literature on the appropriate conduct of fiscal policy against the background of boom-bust cycles in asset prices is relatively small. The reason for this seems to be that the standard prescriptions for fiscal policy are mostly assumed to carry over to an environment of large asset price swings, that is, fiscal policy should follow stable and transparent rules that allow automatic fiscal stabilizers to operate fully while refraining from the temptation to use discretionary countercyclical policy owing to the likely decision and implementation lags.

As a preview of the main data used in this paper, Figure 1 shows series on fiscal balances, asset prices, and real GDP growth for 16 industrial countries since 1971. The fiscal balances cover the general government and are expressed as a percent of GDP; the asset prices provide a summary indicator of prices in equity markets, and residential and commercial property markets, and are expressed in real terms adjusted for mean growth. ${ }^{4}$ The data point to close positive comovements between persistent swings in fiscal balances and in asset prices. While Figure 1's descriptive data display tells us little about the directions of causality in the data, it suggests at a minimum that the potential linkages between large-scale asset price cycles and fiscal positions should be of interest to fiscal policymakers.

\footnotetext{
2 Borio and Lowe (2002) and the May 2000 World Economic Outlook discuss possible mechanisms for generating boom-bust cycles in asset prices.

${ }^{3}$ See the references in Detken and Smets (2003).

${ }^{4}$ Section II provides more information on the data.
} 
Figure 1. Asset Prices, GDP Growth, and Fiscal Balance, 1971-2002
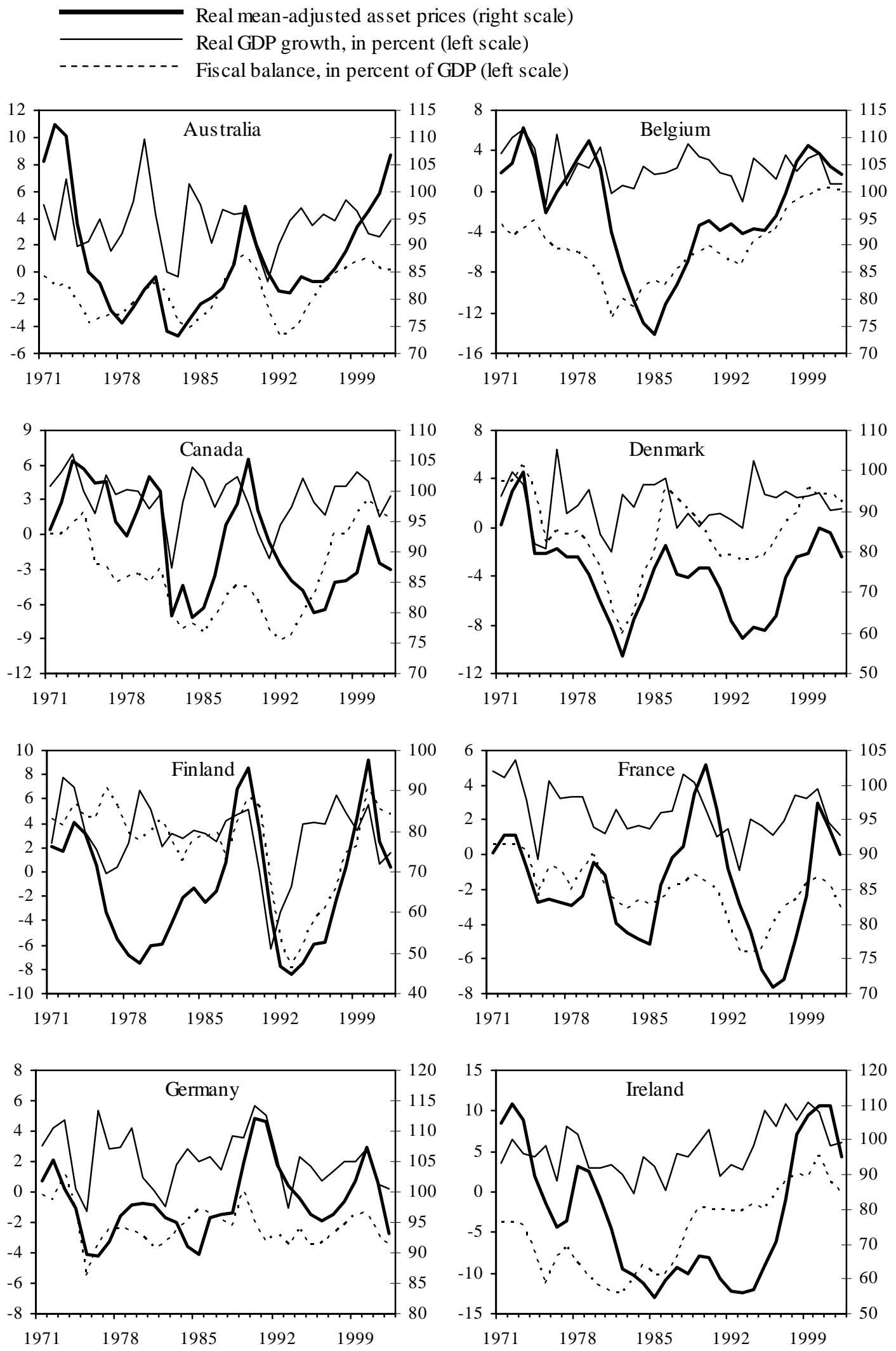
Figure 1 (continued). Asset Prices, GDP Growth, and Fiscal Balance, 1971-2002
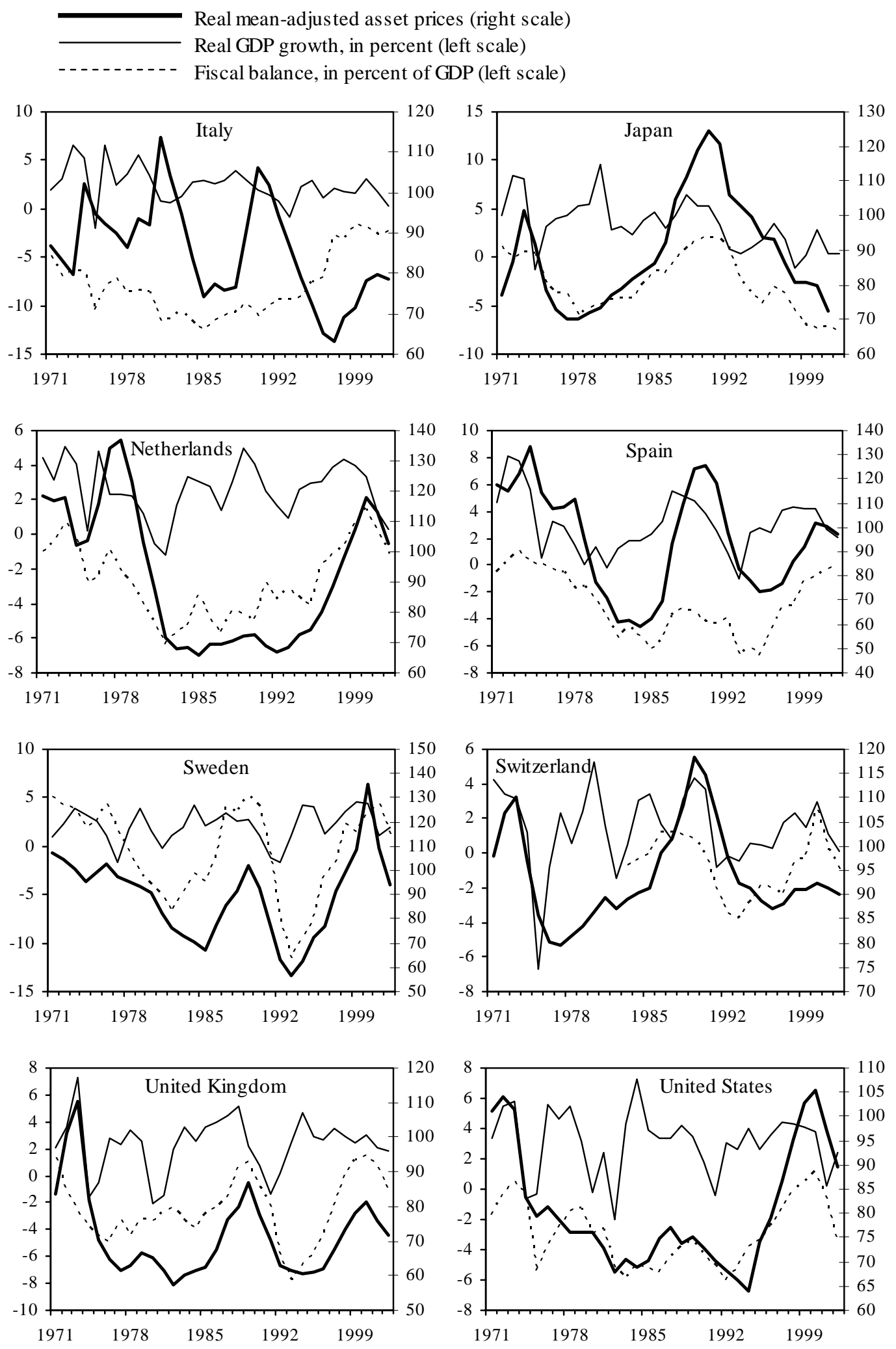

Source: AMECO and own calculations. 
This paper seeks to provide a review of the behavior of fiscal policy during asset price cycles in industrial countries since 1970, focusing on useful lessons that can be gleaned from the accumulated experience of industrial countries. The paper has four main themes:

- $\quad$ As regards the macroeconomic environment of fiscal policymaking, boom and bust phases in asset prices are associated with significantly larger-than-usual uncertainty about both the economy's growth prospects and the size of the economy's output gap. In particular, at the beginning of asset price boom periods, forecasters tend to persistently underestimate output growth. As the boom persists, output gaps tend to be underestimated when the boom reaches its peak. The opposite observations apply to asset price bust periods. The apparent persistence of misjudgments by forecasters and analysts may, however, in part reflect the relative novelty of boom-bust cycles in asset prices. There is also some evidence that contractions in economic activity following asset price booms tend to be much more protracted in low-inflation compared to higher-inflation environments.

- $\quad$ On the revenue side of budgets, persistent forecast errors for output growth imply persistent "revenue surprises” when budget outcomes are compared with plans. More importantly, however, the automatic cyclical responsiveness of taxes to real output growth seems to be larger than normal during boom-bust phases in asset prices. Revenue related to capital gains or losses and turnover taxes as well as wealth effects on consumption boost revenue disproportionately during booms but also adversely affect receipts during busts. ${ }^{5}$ As a policy response to these revenue developments, procyclical tax cuts during booms and increases during downturns are frequently introduced.

- $\quad$ On the spending side of budgets, pressures to spend the above-mentioned "revenue windfalls" build up during the boom. These pressures tend to be particularly pronounced in countries where fiscal institutions establish a tight link between revenue and spending, the most obvious examples being balanced-budget rules at lower levels of government or pay-as-you-go (PAYG) financing rules for social security. In the bust phase, the lagged effects of spending dynamics put in place during the boom phase and additional outlays related to the downturn (sometimes also reflecting the fiscal "clean up cost" of the asset price bust) drive up the primary spending ratio. During a protracted bust phase, with the fiscal situation deteriorating dramatically because the combined revenue and spending effects, a sharp procyclical expenditure reduction can often be observed.

- $\quad$ Combining the stylized observations for revenue and spending developments during boom-bust asset price cycles, fiscal balances tend to improve during the boom but

\footnotetext{
${ }^{5}$ Eschenbach and Schuknecht (2002a). For the early 1990s boom-bust asset price cycles in Sweden and the United Kingdom, see Eschenbach and Schuknecht (2002b).
} 
deteriorate significantly during bust phases. As a consequence, public debt ratios tend to ratchet up over full boom-bust cycles, leaving public finances in a weaker position. ${ }^{6}$

Against this backdrop, our paper argues that conventional views on the appropriate role of fiscal policy in an environment of asset price boom and bust phases may be unsatisfactory for several reasons. This, in turn, gives rise to several policy lessons:

- $\quad$ First, there are operational difficulties in implementing the "let the automatic stabilizers work” prescription in a boom-bust cycle environment. In particular it may be more difficult to gauge the size of the stabilizers and, thereby, the change in the structural balance and the fiscal stance. In particular, fiscal policymakers should be cautious in interpreting improvements in the fiscal position during booms, as they may largely reflect persistent but nonetheless transitory effects of the asset price boom on fiscal revenues.

- $\quad$ Second, to the extent that asset price bust phases are accompanied by prolonged slowgrowth phases, the argument that decision and implementation lags of fiscal policy hinder effective discretionary anticyclical fiscal policy actions may not be as compelling as traditionally perceived. However, the appropriate direction of discretionary policies is not obvious.

- Third and linking up to the previous point, the propagation mechanisms of boom-bust cycles in asset prices, in particular their intimate link to the balance sheet structures and positions of the private sector, may require a rethink of what type of fiscal policy changes is effective in stabilizing the economy. The type of fiscal policy actions that is effective during bust phases may need to support private sector balance sheet repair efforts rather than simply provide a short-term stimulus to demand.

- $\quad$ Fourth, the persistence and magnitude of asset price cycles may enhance fiscal policy and management biases, exacerbating well-known spending and deficit biases. This reinforces the need for mechanisms and institutions that secure the long-term soundness of fiscal policies. Rules promoting cautious expenditure growth and sound balances over the average of the cycle, therefore, seem particularly warranted in boom-bust environments.

- $\quad$ Finally, "stable and transparent rules" that work well in a more normal business cycle environment may not operate as well in a boom-bust cycle environment. In particular,

\footnotetext{
${ }^{6}$ Asset price cycles have been found to contribute significantly to the deterioration in public finances in both industrialized and emerging market countries, especially when resulting in financial crises, see inter alia Honahon and Klingebiel (2003), Eschenbach and Schuknecht (2002b), Collyns and Kincaid (2003), and Manasse, Roubini, and Schimmelpfennig (2003). Hemming, Kell, and Schimmelpfennig (2003) find improving fiscal balances and rising public spending in prefinancial crises booms in a number of emerging market countries.
} 
fiscal institutions or rules that impart a strong procyclical bent to fiscal policyessentially balanced-budget rules_ — can be destabilizing during large asset price cycles. Put differently, boom-bust cycles in asset prices put a premium on fiscal rules that allow for considerable volatility in fiscal deficits. And even fiscal policy rules that are in principle designed to preserve the operation of automatic stabilizers (such as the Stability and Growth Pact (SGP)) may not allow sufficient leeway to accommodate fully the fiscal stabilizers during drawn-out bust phases.

For the design and implementation of robust fiscal rules, these stylized findings for boombust phases in asset prices seem to pose a formidable challenge: How to, on the one hand, secure appropriate fiscal flexibility when cyclical swings in output growth are more protracted and the effects of cycles on fiscal balances are more pronounced than under normal macroeconomic circumstances, while, on the other hand, credibly anchor expectations about the long-term sustainability of public finances?

The rest of this paper is organized as follows. Section II discusses the identification of boombust cycles in asset prices. Section III provides evidence on the pronounced difficulties surrounding forecasting and assessing the nature of growth developments during sharp asset price swings. Section IV documents stylized facts regarding the behavior of fiscal variables (revenue, spending, balance, debt) during asset price cycles. Section V discusses normative aspects, drawing broad conclusions for appropriate fiscal policy behavior during boom-bust cycles. Section VI concludes.

\section{Identifying Boom And Bust Phases in Asset Prices}

There is no obvious or correct way to date boom and bust phases in asset prices. ${ }^{7}$ In this paper, boom and bust phases in real asset prices are determined using a dating approach that largely follows in the footsteps of Harding and Pagan (2002). First, for each country we determine turning points in the real asset price series, that is the peaks and troughs in the series. Denoting the logarithm of an annual real asset price series by $\mathrm{x}_{\mathrm{t}}$ and its average growth rate by $\mu$, a sequence $\left\{\left(\Delta \mathrm{x}_{t}-\mu\right)>0,\left(\Delta \mathrm{x}_{\mathrm{t}+1}-\mu\right)<0\right\}$ identifies a peak in the series, while an asset price growth rate sequence $\left\{\left(\Delta x_{t}-\mu\right)<0,\left(\Delta x_{t+1}-\mu\right)>0\right\}$ identifies a trough. Second, we determine the duration of the ith phase $\left(\mathrm{D}_{\mathrm{i}}\right)$ of an asset cycle, with $\mathrm{D}_{\mathrm{i}}$ denoting the duration of either a trough-to-peak (TP) or a peak-to-trough (PT) asset price movement. Third, the amplitude of the ith phase $\left(\mathrm{A}_{\mathrm{i}}\right)$ is measured as the cumulative percentage change in asset prices (adjusted for mean-growth) in that phase. Fourth, to calculate the cumulative movement in asset prices in the ith phase we use the "triangle approximation" $0.5\left(D_{i} A_{i}\right)$, which proxies the cumulative change in asset prices during the ith phase. And fifth, to separate "booms" and "busts" in asset prices from more "normal” asset price cycles, we pick the top quintiles from the distributions of TP and PT triangle approximations for all countries, respectively. We note that this approach to identifying asset price swings does not entail that a boom (or bust) phase has to be followed by a bust (or boom) phase.

${ }^{7}$ See Bordo and Jeanne (2003), the April 2003 World Economic Outlook, and Detken and Smets (2003) for other approaches to dating asset price booms and busts. 
As the indicator for asset prices the paper uses the Bank for International Settlements' (BIS) measure of annual real asset prices, which is available for almost all industrial countries for 1970-2002. ${ }^{8}$ This index combines price indices for three different asset classes-equities, residential property, and commercial property_-by weighing the components using the shares of the asset classes in private sector wealth; the private consumption deflator is used to convert nominal to real asset price indices. The selected asset classes were included in the index by the BIS because, first, together they usually make up most of the private sector's wealth and, second, these assets are traded with some frequency in well-organized markets. ${ }^{9}$

The results of applying the paper's particular dating approach are presented in Figure 2 and Tables 1 and 2. First, based on the statistical characteristics of asset prices in Table 1, the time duration of booms or busts in asset prices seems to mostly range from 5-7 years for both boom and bust phases, suggesting that boom or bust phases are quite prolonged relative to the length of "normal" asset price phases (1-3 years). Second, large and persistent fluctuations in asset prices have occurred mainly since the early 1980s, suggesting that they are a relatively recent phenomenon (Figure 1). Third, the size distribution of individual boom and bust phases in Table 2 highlights that a significant number of countries went through asset price booms during the second half of the 1990s. In fact, only Japan was in a bust phase during the second half of the 1990s. The size distribution also illustrates the out-of-theordinary size of both Japan's 1979-90 boom and the 1991-present bust phase.

This paper's dating results for boom and bust phases in asset prices are not easily compared with the results from alternative dating approaches, in large part because, given our particular interest in fiscal policy behavior, we focus on an annual aggregate asset price index while other work has identified cycles for the underlying asset price components, i.e. equity and residential real estate, or has used quarterly data. Detken and Smets (2003) use a related approach but focus on boom phases only. A Hodrick-Prescott filter is applied to the BIS's aggregate price index measure to identify phases where asset prices are 10 percent above trend for several years, which are classified as "boom phases." While these authors find more boom phases than reported here, probably reflecting a less stringent cutoff criterion, they tend to identify a closely overlapping set of boom instances, particularly during the 1990s.

\footnotetext{
${ }^{8}$ The data used in this paper cover 16 industrial countries including the seven major industrial countries, Australia, Belgium, Denmark, Finland, Ireland, the Netherlands, Spain, Sweden, and Switzerland. The series for Spain starts in 1971.

${ }^{9}$ The details of the methodology for constructing the BIS's aggregate asset price index is discussed in Borio, Kennedy, and Prowse (1994, Appendix I).
} 
Figure 2. Boom-Bust Phases in Asset Prices, 1970 - 2002
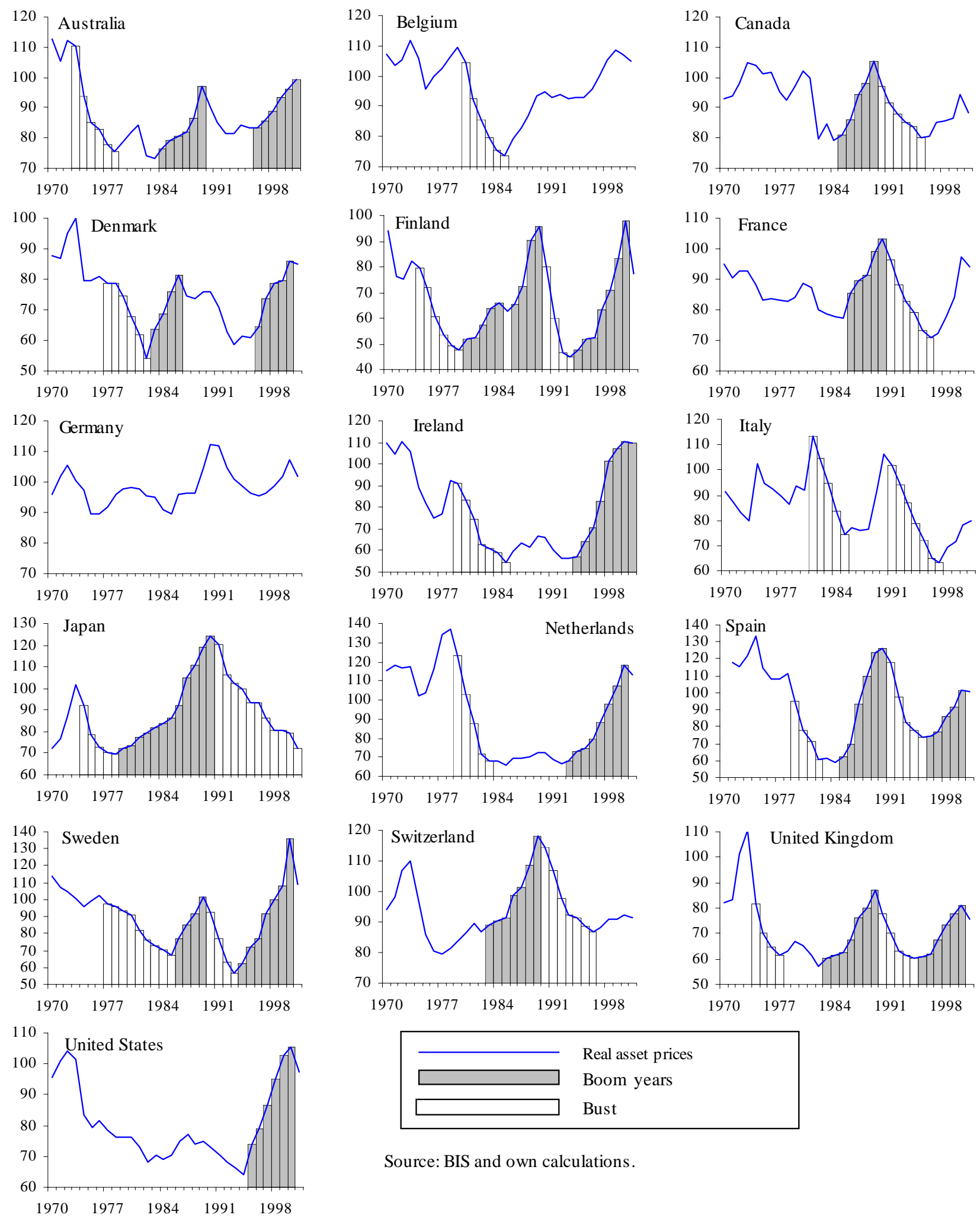

Source: BIS and own calculations. 
Table 1. Characteristics of Asset Price Cycles in Industrial Countries, 1970-2002 1/

\begin{tabular}{lrrr}
\hline & $\begin{array}{c}\text { All } \\
\text { Phases }\end{array}$ & $\begin{array}{c}\text { Boom-Bust } \\
\text { Phases }\end{array}$ & $\begin{array}{r}\text { Other } \\
\text { Phases }\end{array}$ \\
\hline & & & \\
Mean duration (years) & & & \\
Trough to Peak (TP) & 2.7 & 5.4 & 1.8 \\
& $(2.0)$ & $(1.8)$ & $(1.0)$ \\
Peak to Trough (PT) & 2.6 & 5.0 & 1.9 \\
& $(1.8)$ & $(1.9)$ & $(0.9)$ \\
Cumulative price changes (percent) 2/ & & & \\
Trough to Peak (TP) & 50.3 & 155.9 & 15.1 \\
& $(79.3)$ & $(97.2)$ & $(18.6)$ \\
Peak to Trough (PT) & -42.2 & -134.5 & -14.2 \\
& $(60.7)$ & $(18.6)$ & $(15.9)$ \\
& & & \\
\hline
\end{tabular}

Sources: BIS asset price data; authors' estimates.

1/ Figures in parentheses are standard errors.

2/ Triangular approximation.

Table 2. Industrial Countries: Size Distribution of Identified Boom and Bust Phases in Real Asset Prices, 1970-2002

\begin{tabular}{|c|c|c|c|c|c|}
\hline \multirow{2}{*}{$\begin{array}{l}\text { Boom Phases } \\
\text { Country }\end{array}$} & \multicolumn{5}{|c|}{ Bust Phases } \\
\hline & Years & $\begin{array}{r}\text { Cumulative } \\
\text { price change } 1 /\end{array}$ & Country & Years & $\begin{array}{l}\text { Cumulative } \\
\text { price change } 1 /\end{array}$ \\
\hline Japan & 1979-1990 & 358.0 & Japan & 1991-2002 & -364.1 \\
\hline Sweden & 1994-2000 & 329.6 & Sweden & $1977-1985$ & -185.1 \\
\hline Finland & $1994-2000$ & 293.1 & Irland & 1979-1985 & -173.3 \\
\hline Ireland & 1994-2001 & 289.1 & Italy & 1991-1997 & -173.1 \\
\hline Spain & 1985-1990 & 249.4 & Netherlands & 1979-1983 & -163.0 \\
\hline Netherlands & 1993-2000 & 237.2 & Finland & 1974-1979 & -155.1 \\
\hline United States & $1995-2000$ & 157.8 & Finland & 1990-1993 & -135.4 \\
\hline United Kingdom & 1983-1989 & 152.1 & Spain & 1991-1995 & -124.6 \\
\hline Switzerland & 1983-1989 & 110.9 & Belgium & 1980-1985 & -115.2 \\
\hline Finland & 1986-1989 & 92.2 & Denmark & $1977-1982$ & -113.5 \\
\hline Denmark & 1996-2000 & 90.6 & Australia & 1973-1978 & -113.4 \\
\hline United Kingdom & $1995-2000$ & 90.4 & Spain & 1979-1982 & -111.3 \\
\hline Australia & 1996-2002 & 89.2 & France & 1991-1996 & -108.6 \\
\hline Sweden & 1986-1989 & 88.1 & Sweden & $1990-1993$ & -108.0 \\
\hline Australia & 1984-1989 & 87.7 & United Kingdom & 1974-1977 & -106.3 \\
\hline Denmark & 1983-1986 & 85.9 & Switzerland & 1990-1996 & -104.0 \\
\hline Finland & 1980-1984 & 84.9 & Japan & 1974-1978 & -88.1 \\
\hline Spain & 1996-2000 & 84.0 & United Kingdom & 1990-1994 & -86.1 \\
\hline France & 1986-1990 & 74.6 & Italy & $1981-1985$ & -80.7 \\
\hline Canada & 1985-1989 & 74.3 & Canada & 1990-1995 & -80.2 \\
\hline
\end{tabular}

Sources: BIS asset price data; authors' estimates.

1/ Triangular approximation. 


\section{Asset Price Swings and Gauging Output Developments}

For fiscal policymakers, projecting output growth and gauging the size of the output gap are exercises that provide key inputs into planning and decision making. A quantitative growth outlook is needed for budget planning, for example to project tax bases. And an assessment of the size of the output gap is needed to gauge the strength of the underlying fiscal position and the cyclical stance of policy. This section concludes that the available record on projections of output growth and assessments of output gaps against the backdrop of boom or bust phases in asset prices points to highly persistent misjudgments by forecasters and analysts.

Boom and bust phases in asset prices are associated with large and persistent deviations of output growth from trend, particularly during downturns (Figure 3). Figure 4 presents the growth pattern for the average of the identified boom bust phases, that is, a "representative case study." Booms (ending in $\mathrm{t} 0$ ) feature strong, above-average growth whereas busts (starting in t1) are initially accompanied by a steep decline to below average rates.

The picture of increasing correlation between boom-bust and real economic cycles is confirmed when analyzing the co-movement between changes in real output and asset prices. Looking at correlation coefficients, we find that the correlation between the two variables is increasing over time from 0.51 for $1971-1985$ to 0.64 for the period $1985-2003$. When conducting a 15-year-rolling-window analysis of correlation coefficients, we find that correlation increases from 0.5 in the first window (1971-85) to nearly 0.7 for the last window (1988-2002) (Figure 5).

These stylized facts are consistent with the financial accelerator literature. The latter predicts an increasing interrelation between the financial and real economy via asset prices and net worth when private sector leverage increases. ${ }^{10}$ However, private sector debt and net worth data is relatively scarce and sufficiently long time series are only available for a few industrialized countries. Nevertheless, the available data as published for example by central banks suggest strongly increasing private sector indebtedness (in percent of GDP) since the early 1980s. Household and corporate debt ratios in major industrialized countries, for example, have increased at least by half (e.g., from about 100 to 150 percent of GDP in the case of Germany) and only in Japan has corporate debt declined significantly in the context of the subsequent bust phase.

As a consequence of the high persistence of asset price boom and bust phases, not only can expansionary phases of the business cycle be quite prolonged but contractionary phases can also be quite protracted. Historical data examined in Zarnowitz (1985) suggest that prolonged phases of low or even negative growth in business cycles seem to be novel feature of cycles during the 1980s and 1990s. The mean duration of U.S. cyclical expansions during the period

${ }^{10}$ See Bernanke, Gilquist, and Gertler (1999). 
Figure 3. Real GDP Growth and Asset Price Cycles, 1971 - 2002
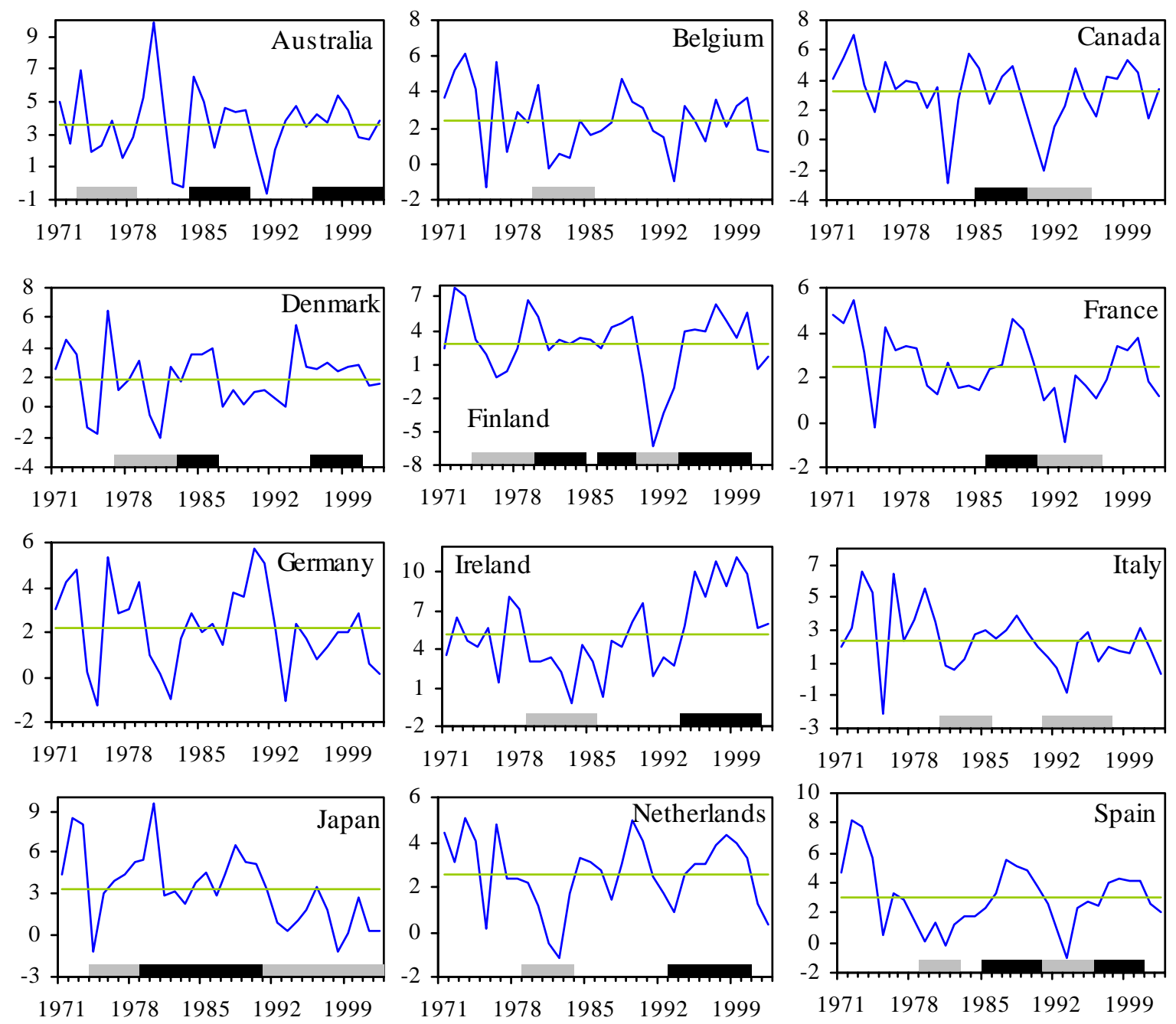

19711978198519921999
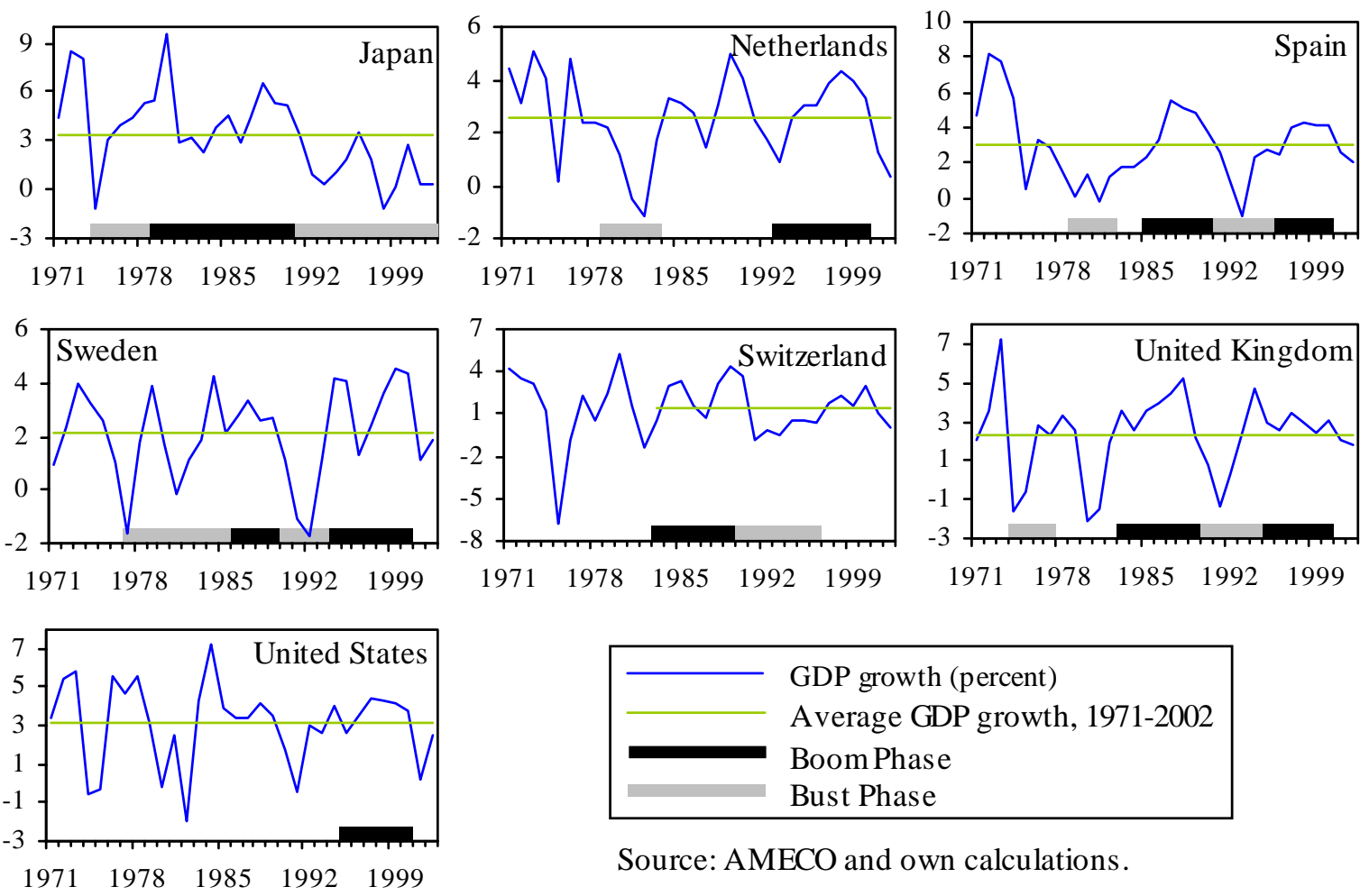

Source: AMECO and own calculations. 
Figure 4: Real Economic Growth in "Typical" Boom-Bust Phase

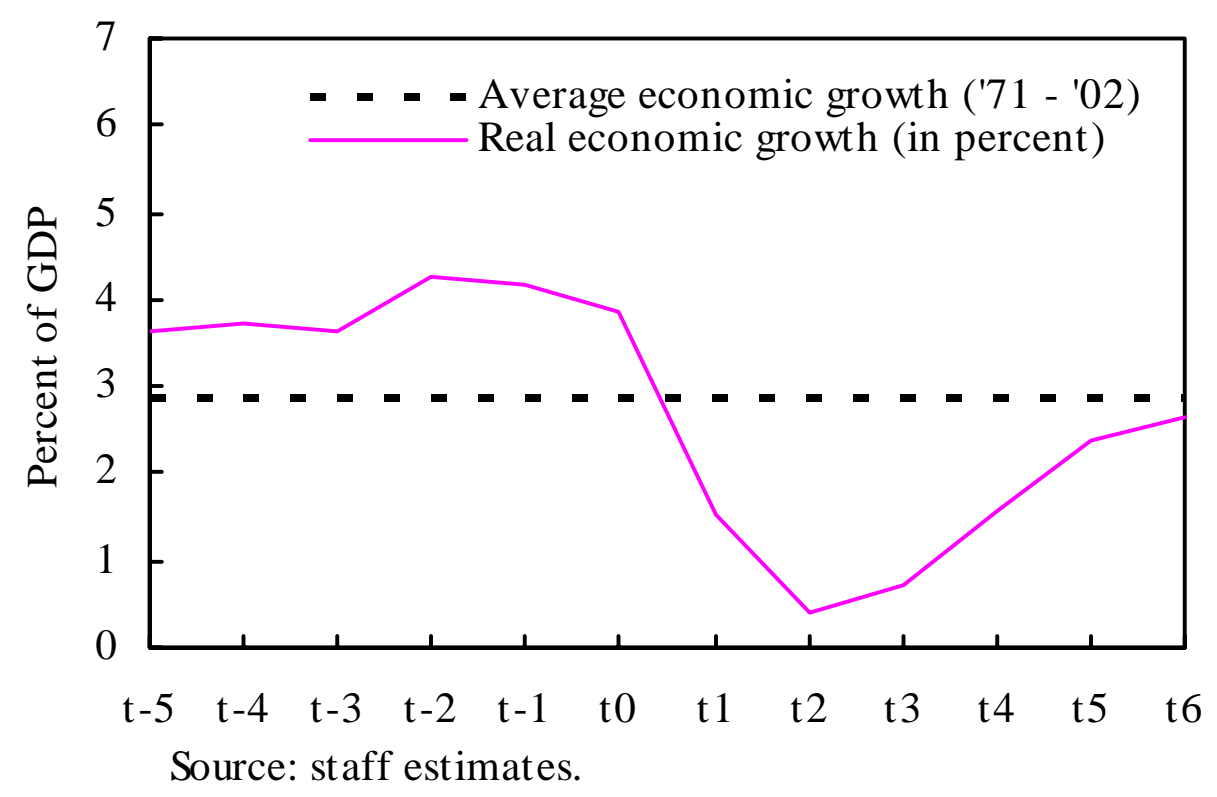

Figure 5. Correlation Coefficient; Changes in Real Asset Prices and Real Output

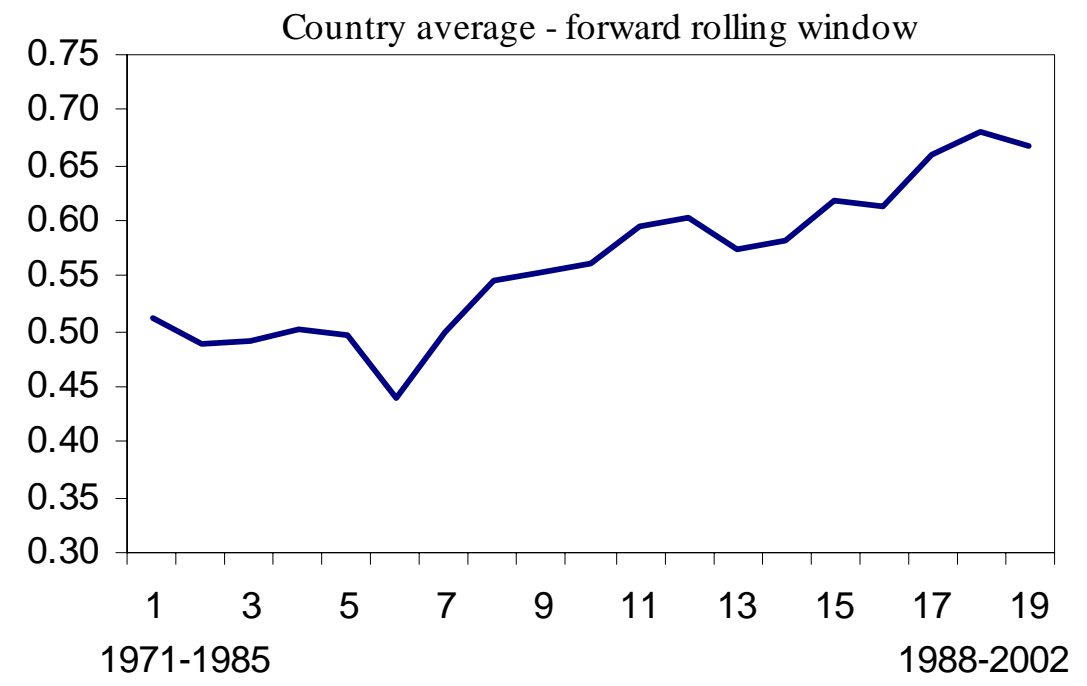

Source: staff estimates. 
1933-1985 was about 4 years, while the mean duration of U.S. contractions amounted to only about 1 year, with little variation around this mean value. At the same time, Zarnowitz points out that U.S. contractions before the 1933-1985 period used to be considerably longer (about 2 years, but with considerable variation around this mean). ${ }^{11}$

As regards the behavior of the different demand components, boom and bust phases in asset prices are closely synchronized with similar swings in gross fixed investment and, to a lesser extent, in private consumption (Table 3). In fact, investment declines and increases cumulatively by roughly 25 percent of GDP relative to trend during boom-bust phases. We also note in passing that the cumulative deviations of output growth from mean during boom and bust phases seem to have increased over time. For example the asset price busts in the early 1990s have been more costly in terms of cumulated output growth losses than the busts in the 1970s and early 1980s. This raises the question whether the shift to a low-inflation environment over the last two decades has exacerbated the amplitude and persistence of output swings in response to large asset price cycles, particularly during downturns. The reason could be that low inflation rates slow down required balance sheet adjustments following the bursting of asset price bubbles.

There is some casual evidence linking low-inflation environments to more protracted bust phases in asset prices and output growth. Figure 6 plots the rate of inflation near the turning point from boom to bust against the duration (in years) of the subsequent downturn for all bust episodes in our sample. The steeply downward-sloped line reflects the strong negative correlation between inflation and the length of the bust for episodes in the early 1990s. This relationship remains intact when removing the observation for Japan in the upper left corner. The relationship is, however, much less convincing for the busts of the late 1970s, a period when inflation sometimes reached 20 percent and other factors may have dominated bust patterns (as reflected in the second, much flatter, line in Figure 6).

This finding may be due to the fact that imbalances due to a boom in real estate prices take longer to correct in low inflation environments because real estate prices tend to be nominally downward-sticky (as house owners would rather stay put than sell their house and pay up for the realized loss). If inflation is relatively high, two factors facilitate the adjustment of imbalances in real estate markets. First, the real value of houses can decline significantly even with nominally unchanged prices so that imbalances in real estate prices are likely to disappear relatively fast. Second, the nominal interest rate is high and contains a significant rate of implicit amortization. This means that equity is built much faster than in a low inflation environment where inflation-induced amortization is much smaller. Therefore, a higher-inflation-rate environment speeds up the process of balance sheet repair after a boom as compared to a low inflation environment.

${ }^{11}$ Zarnowitz's (1985) cycle dating procedure uses, however, turning points in the level of the cyclical reference series, and the duration of contractions therefore tends to be shorter compared with dating procedures that use growth rates to pick cyclical turning points. It would be interesting to examine whether the asset price and growth patterns observed more recently imply a return to pre-1933 cyclical patterns. 
Table 3. Real GDP Growth Forecast Errors During Boom-Bust Cycles in Asset Prices 1/

\begin{tabular}{|c|c|c|c|c|c|c|c|c|c|}
\hline \multicolumn{5}{|l|}{ Booms } & \multicolumn{5}{|l|}{ Busts } \\
\hline \multirow[b]{2}{*}{ Country } & \multirow[b]{2}{*}{ Years } & \multicolumn{3}{|c|}{ Average Forecast Error 2/ } & \multirow[b]{2}{*}{ Country } & \multirow[b]{2}{*}{ Years } & \multicolumn{3}{|c|}{ Average Forecast Error 2/ } \\
\hline & & $\begin{array}{r}\text { All } \\
\text { years }\end{array}$ & $\begin{array}{r}\text { First } \\
\text { half }\end{array}$ & $\begin{array}{r}\text { Second } \\
\text { half }\end{array}$ & & & $\begin{array}{r}\text { All } \\
\text { years }\end{array}$ & $\begin{array}{r}\text { First } \\
\text { half }\end{array}$ & $\begin{array}{r}\text { Second } \\
\text { half }\end{array}$ \\
\hline Japan & $1979-1990$ & 0.7 & 0.5 & 0.9 & Japan & 1991-2002 & -0.4 & -0.4 & -0.3 \\
\hline Sweden & $1994-2000$ & 1.2 & 1.1 & 1.3 & Italy & 1991-1997 & -0.6 & -0.9 & -0.2 \\
\hline Finland & $1994-2000$ & 1.5 & 1.4 & 1.5 & Finland & 1990-1993 & -3.6 & -4.2 & -3.0 \\
\hline Ireland & $1994-2001$ & 2.6 & 3.7 & 1.6 & Spain & 1991-1995 & -0.5 & -1.4 & 0.7 \\
\hline Spain & $1985-1990$ & 0.9 & 1.1 & 0.7 & France & 1991-1996 & -1.0 & -1.5 & -0.5 \\
\hline Netherlands & $1993-2000$ & 0.8 & 0.6 & 0.9 & Sweden & 1990-1993 & 0.0 & -0.4 & -0.3 \\
\hline United States & $1995-2000$ & 1.3 & 0.9 & 1.6 & United Kingdom & 1990-1994 & -0.3 & -1.5 & 1.4 \\
\hline United Kingdom & 1983-1989 & 1.2 & 1.3 & 1.1 & Canada & 1990-1995 & -1.4 & -2.0 & -0.1 \\
\hline Finland & 1986-1989 & 1.8 & 1.2 & 2.4 & & & & & \\
\hline Denmark & $1996-2000$ & 0.3 & -0.3 & 1.0 & Average & & -1.0 & -1.5 & -0.3 \\
\hline United Kingdom & $1995-2000$ & 0.4 & 0.0 & 0.9 & Standard deviation & & 1.1 & 1.2 & 1.3 \\
\hline Australia & 1996-2002 & 0.7 & 1.3 & -0.2 & & & & & \\
\hline Sweden & 1986-1989 & 1.6 & 2.2 & 1.0 & & & & & \\
\hline Australia & 1984-1989 & 1.3 & 0.7 & 2.0 & & & & & \\
\hline Denmark & $1983-1986$ & 1.5 & 2.2 & 0.7 & & & & & \\
\hline Spain & $1996-2000$ & 0.6 & 0.5 & 0.6 & & & & & \\
\hline France & $1986-1990$ & 0.9 & 0.3 & 1.3 & & & & & \\
\hline Canada & $1985-1989$ & 1.0 & 1.0 & 0.9 & & & & & \\
\hline Average & & 1.1 & 1.1 & 1.1 & & & & & \\
\hline Standard deviation & & 0.6 & 0.9 & 0.6 & & & & & \\
\hline
\end{tabular}

Sources: OECD Economic Outlook (December issues); and authors' estimates.

1/ One-year ahead forecast errors based on OECD projections of real GDP growth.

2/ In percent.

Figure 6: Inflation and Length of Downturns During Busts

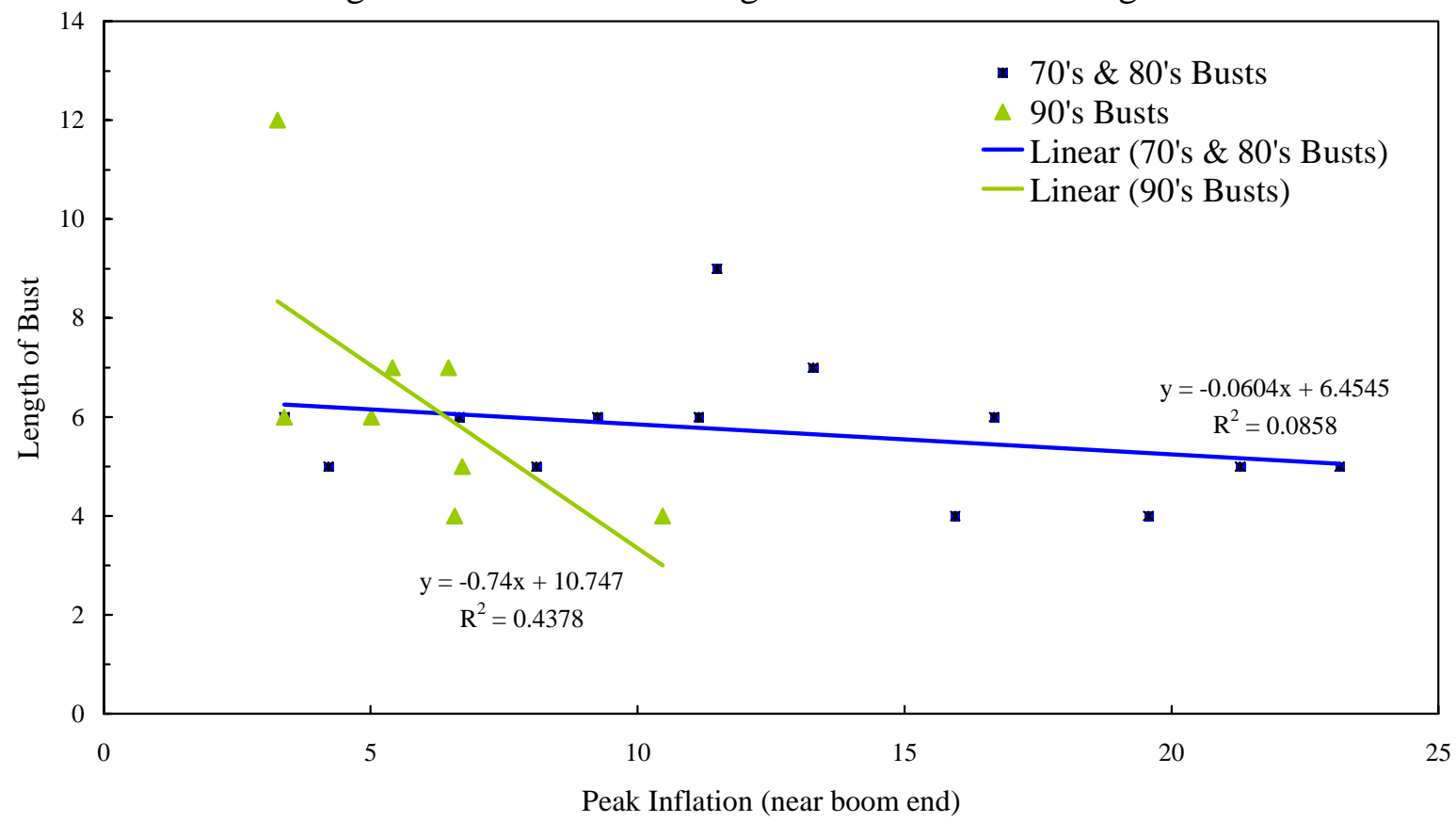

Source: staff estimates. 
More rapid adjustment, however, comes at a cost. With real asset prices falling faster in an inflationary environment, its collateral value also falls much faster in real terms. This has stronger adverse effects on consumption and investment in the short run than the slow fall of real asset prices in a more stable environment. This could explain the more pronounced (vshaped) episodes where busts are accompanied by relatively high inflation rates (partly facilitated by exchange rate depreciations) as compared to the "hammock" (or u-shaped) downturns in low-inflation countries. Examples from the early 1990s of the former include the experience of the U.K., Sweden, and Finland, while the latter feature can be found in France, Switzerland, or Japan during the same period.

During boom-bust cycles in asset prices, projections of real output growth are systematically biased, with forecasts consistently underestimating output growth during booms and vice versa during busts. OECD projections published twice a year in the OECD Economic Outlook provide the most comprehensive set of forecasts of real output growth (and fiscal balances) for industrial countries over the last three decades. Nevertheless, for many of the smaller industrial countries forecasts are only available starting in the 1980s or even later. As a consequence, the sample of boom-bust cycles for which one-year ahead forecast errors can be studied is restricted, particularly as regards asset price busts. The available data suggest that average output growth forecast errors during booms amount to about 1 percent, but with considerable variation around this mean (Table 4). In addition, the pattern of forecast errors during the boom suggests that underestimation is similar in the first and second half of the boom, although uncertainty (as measured by the standard deviation of standard errors) seems to be higher during the first half of the boom. During bust periods, forecast errors seem to be much more pronounced during the first half of the bust. Given the typical durations of booms and busts, the average forecast errors can cumulate to sizeable under- or overestimates of output growth over time.

There is also evidence that inertia of forecasters and the biases in their techniques result in large revisions and systematic errors in the measurement and forecasts of output gaps. Regarding the latter point, trend growth estimates are likely to be underestimated at the beginning of the boom leading to an overestimation of the output gap. As strong growth continues, economists are likely to factor this into their trend growth and output gap calculations. As the boom proceeds, the assessment is likely to swing to overly optimistic trend growth and output gap figures that prevail well into the bust when ultimately figures need to be adjusted again. Regarding the first point, persistent trend growth mismeasurement (the longer a boom or a bust the more likely this is) or significant growth changes can result in significant ex-post revisions of output gap estimates.

Unfortunately, output gap data has only been published since 1994 for a selection of industrialized countries so that an empirical examination of these errors for the full sample is not possible. Nevertheless, by comparing historic and current output gap estimates for sample episodes for 1993 (bust or near turning point), 1996 (near turning point), and 1999 (boom), we can generate some stylized facts: 
Table 4: Boom Bust Cycles and the Macroeconomic Environment

\begin{tabular}{|c|c|c|c|c|c|c|}
\hline & \multicolumn{2}{|c|}{ Real Economic Growth } & \multicolumn{2}{|c|}{ Real Consumption Growth } & \multicolumn{2}{|c|}{ Real Investment Growth } \\
\hline & $\begin{array}{r}\text { Average } \\
\text { Annual } \\
\text { Growth Rate }\end{array}$ & $\begin{array}{c}\text { Cumulative } \\
\text { Deviation } \\
\text { from Mean }\end{array}$ & $\begin{array}{r}\text { Average } \\
\text { Annual } \\
\text { Growth Rate }\end{array}$ & $\begin{array}{l}\text { Cumulative } \\
\text { Deviation } \\
\text { from Mean }\end{array}$ & $\begin{array}{r}\text { Average } \\
\text { Annual } \\
\text { Growth Rate }\end{array}$ & $\begin{array}{l}\text { Cumulative } \\
\text { Deviation } \\
\text { from Mean }\end{array}$ \\
\hline \multicolumn{7}{|c|}{ (All changes in percent, unless otherwise indicated) } \\
\hline All booms, average & 3.9 & 6.8 & 3.6 & 4.5 & 6.9 & 26.2 \\
\hline All busts, average & 1.3 & -8.6 & 0.8 & -10.7 & -1.8 & -22.5 \\
\hline Busts, 1970s/early 1980s & 1.8 & -6.4 & 1.1 & -9.9 & -0.9 & -20.0 \\
\hline Booms, late 1980s & 3.6 & 5.6 & 3.6 & 4.6 & 6.9 & 24.9 \\
\hline Busts, early 1990s & 0.6 & -11.2 & 0.5 & -11.7 & -2.8 & -25.6 \\
\hline Booms, late 1990s & 4.1 & 8.3 & 3.6 & 4.3 & 6.8 & 27.8 \\
\hline \multicolumn{7}{|l|}{ Memorandum item: } \\
\hline \multirow[t]{6}{*}{ Average all obs. } & 2.9 & -- & 2.7 & -- & 2.8 & -- \\
\hline & & & & Real Effective & Current & Short-Term \\
\hline & & Inflation & & Exchange Rate & Account Bal. & Interest Rate \\
\hline & Average & Cumulative & Maximum & Cumulative & Cumulative & Cumulative \\
\hline & & Change & Near Peak 1/ & Change & Change & Change \\
\hline & & & \multicolumn{4}{|c|}{ (In percent of GDP) } \\
\hline All booms, average & 3.8 & -1.2 & 6.5 & 5.1 & -0.7 & -0.9 \\
\hline All busts, average & 8.2 & -2.6 & & -7.0 & 1.8 & -1.5 \\
\hline Busts, 1970s/early 1980s & 11.8 & -2.2 & 13.9 & -2.9 & 0.9 & 1.9 \\
\hline Booms, late 1980s & 5.1 & -1.9 & 6.2 & 6.3 & -2.0 & 0.5 \\
\hline Busts, early 1990s & 3.7 & -3.0 & 6.2 & -12.7 & 3.0 & -5.0 \\
\hline Booms, late 1990s & 2.2 & -0.2 & 3.4 & 3.8 & 0.9 & -2.6 \\
\hline \multicolumn{7}{|l|}{ Memorandum item: } \\
\hline Average all obs. & 5.8 & -- & -- & -- & -- & --- \\
\hline
\end{tabular}

Source: AMECO and own calculations.

1/ Maximum inflation near boom-bust turning point, between year before peak and second year after peak.

Median instead of average for all booms.

- $\quad$ When comparing historic output gap estimates using the most recent (Autumn 2003) vintage from the World Economic Outlook our hypotheses as to the pattern of measurement errors are broadly confirmed. The set of the first three columns in Table 5 presents 1993 output gap figures for a number of bust episodes. In virtually all cases the output gap was significantly revised downwards after spring 1994 (the output gap was less negative, implying less favorable assumptions about trend growth ex post). The turning point between bust and the next boom is reflected in the next set of columns. In most cases, the output gap was revised upward (it became more negative), implying that economists were too pessimistic when assessing trend growth at that time.

- $\quad$ By 1999, at the height of the latest asset price boom, the tide had again turned and output gaps and trend growth were judged rather optimistically. Here, however, the third and last set of columns reveal that output gap estimates can also differ significantly across organizations. In 2003, the 1999 output gap revisions of the Commissions had been much higher in most countries and on average than those of the WEO. 
Table 5: Output Revisions and Boom-Bust Cycles

\begin{tabular}{|c|c|c|c|c|c|c|c|c|c|c|c|c|}
\hline \multirow{3}{*}{$\begin{array}{l}\text { Year } \\
\text { Source } \\
\text { Vintage/revision }\end{array}$} & \multicolumn{3}{|c|}{ 1993-Bust } & \multicolumn{3}{|c|}{ 1993/96-Turning Point to Boom 1/ } & \multicolumn{3}{|c|}{ 1999-Boom } & \multicolumn{3}{|c|}{ 1999-boom } \\
\hline & \multicolumn{3}{|c|}{ World Economic Outlook } & \multicolumn{3}{|c|}{ World Economic Outlook } & \multicolumn{3}{|c|}{ World Economic Outlook } & \multicolumn{3}{|c|}{ European Commission 2/ } \\
\hline & Spring 1994 & Autumn 2003 & Revision & Spring $19973 /$ & Autumn 2003 & Revision & Spring 2000 & Autumn 2003 & Revision & Spring 2000 & Autumn 2003 & Revision \\
\hline Australia & $--4 /$ & -- & - & 0.0 & 0.1 & 0.1 & 0.0 & 1.1 & 1.0 & -- & -- & - \\
\hline Canada & -5.2 & -1.5 & 3.7 & -- & -- & -- & -- & -- & -- & -- & -- & -- \\
\hline Denmark & -- & -- & -- & -1.2 & -0.3 & 1.0 & 0.6 & 0.2 & -0.4 & 0.6 & 1.4 & 0.8 \\
\hline Finland & -- & -- & -- & -6.6 & -8.9 & -2.3 & 0.1 & -1.8 & -1.9 & 0.6 & 2.4 & 1.8 \\
\hline France & -3.5 & -3.8 & -0.3 & -3.3 & -3.3 & 0.0 & -- & -- & -- & -- & -- & -- \\
\hline Ireland & -- & -- & -- & 0.0 & -1.6 & -1.6 & 3.0 & 3.4 & 0.4 & 3.3 & 4.2 & 0.9 \\
\hline Italy & -3.9 & -2.3 & 1.6 & -- & -- & -- & -- & -- & -- & -- & -- & -- \\
\hline Japan & -3.5 & -0.5 & 3.0 & -- & -- & -- & -- & -- & -- & -- & -- & -- \\
\hline Netherlands & -- & -- & -- & 0.0 & -0.8 & -0.8 & 1.2 & 2.5 & 1.3 & -0.2 & 3.0 & 3.2 \\
\hline Spain & -5.4 & -2.1 & 3.3 & -2.4 & -2.5 & -0.1 & -0.2 & 0.0 & 0.2 & 0.0 & 0.8 & 0.8 \\
\hline Sweden & -- & -- & -- & -2.8 & -5.8 & -3.0 & -2.4 & -1.3 & 1.1 & -0.2 & 1.5 & 1.7 \\
\hline Switzerland & -2.9 & -0.5 & 2.4 & -- & -- & -- & -- & -- & -- & -- & -- & -- \\
\hline United Kingdom & -5.3 & -2.8 & 2.5 & -1.9 & -0.4 & 1.5 & 0.1 & -0.3 & -0.4 & -0.3 & 0.6 & 0.9 \\
\hline United States & -- & -- & -- & 0.5 & -1.6 & -2.1 & 0.3 & 1.2 & 0.9 & -- & -- & -- \\
\hline & & & & -- & -- & -- & & & & & & \\
\hline Average & -4.3 & -1.9 & 2.3 & -1.8 & -2.5 & -0.7 & 0.3 & 0.5 & 0.2 & 0.5 & 2.0 & 1.4 \\
\hline Standard deviation & 1.0 & 1.2 & 1.3 & 2.2 & 2.8 & 1.5 & 1.4 & 1.7 & 1.0 & 1.3 & 1.3 & 0.9 \\
\hline
\end{tabular}

Source: WEO, AMECO, European Commission forecasts and own calculations.

1/ Finland and Sweden = 1993, all other countries 1996.

2/ EU countries only.

3/ Except Finland and Sweden=spring 1994

4/ Missing values imply no bust in early 1990s or no boom in late 1990s. 
- $\quad$ The magnitude of revisions has also been significant: 1993 figures were revised by over 2 percent on average. Revisions in the autumn 2003 vintage of Commission data for 1999 average 1.4 percent in absolute terms as compared to the spring 2000 vintage.

\section{Asset Price Swings, Fiscal Developments and Policy Behavior}

This section provides a stylized description of fiscal developments and policy behavior during boom and bust phases in asset prices. The data suggest that fiscal balances respond more strongly to a given change in output growth during boom and bust phases in asset prices compared with phases of "normal” macroeconomic fluctuations. Put differently, automatic fiscal stabilizers during boom or bust phases are significantly larger than conventionally assumed, mainly due to higher revenue elasticities associated with the asset price boom. At the same time, the fiscal policy responses to boom and bust phases in asset prices seem to be asymmetric — revenue windfalls during boom phases are partly spent on tax cuts or an acceleration in spending growth, a policy often underpinned by overly optimistic assessments of structural balances or by fiscal institutions (balanced budget rules) that induce a procyclical fiscal stance during "good times." At the same time, fiscal retrenchment efforts during bust phases are slow to materialize, inertia that typically results in severe deteriorations in fiscal balances. Reflecting this asymmetric fiscal policy behavior, revenue and expenditure ratios over boom-bust phases tend to ratchet up. The high fiscal deficits during bust phases - sometimes also including private sector bailout costs-drive up public debt, in particular during drawn-out bust phases.

\section{A. Fiscal Balances and Debt}

Asset price boom bust phases during the past 25 years have typically been associated with marked average deficits. At the start of boom phases, fiscal deficits were on average over 4 percent of GDP; as the boom came to an end, budgets were on average near-balance (Table 6). Subsequently, fiscal balances worsened by almost 5 percent of GDP in busts. These averages reflect slightly less favorable developments in the earlier busts and booms up to about 1990, and confirm the claim that especially European countries featured more stabilityoriented fiscal policies since then. ${ }^{12}$

The stylized pattern of fiscal balance developments over boom-bust phases is illustrated in Figure 7, panel a, which provides a representative case study for boom-bust episodes based on the average for the identified episodes (analogous to Figure 2 above). Fiscal balances improve gradually over 5 years (from t-5) until the turning point between boom and bust

${ }^{12}$ For surveys on the behavior of fiscal policies in EU countries under the SGP framework, see Buti, Eijffinger and Franco (2003) and Fatas, von Hagen, Hughes Hallet, Sibert and Strauch (2003) and Briotti (2004). 
phases (t0). Subsequently, public finances deteriorate rapidly until $t+3$ before stabilizing and improving again before the bust is over.

Table 6: Boom-Bust Cycles, Fiscal Balances, and Public Debt

\begin{tabular}{|c|c|c|c|}
\hline & \multicolumn{2}{|c|}{ Fiscal Balance Ratio } & \multirow{2}{*}{$\begin{array}{c}\text { Public Debt Ratio } \\
\text { Change: } \\
\text { Boom Bust }\end{array}$} \\
\hline & $\begin{array}{c}\text { Before: } \\
\text { Boom Bust }\end{array}$ & $\begin{array}{l}\text { Change: } \\
\text { Boom Bust }\end{array}$ & \\
\hline & \multicolumn{3}{|c|}{ (In percentage points of GDP) } \\
\hline All booms, average & -4.1 & 5.6 & -8.5 \\
\hline All busts, average & -0.4 & -4.6 & 28.3 \\
\hline Busts, 1970s/early 1980s & -3.1 & -3.9 & 25.5 \\
\hline Booms, late 1980s & -3.3 & 4.8 & -2.5 \\
\hline Busts, early 1990s & 0.2 & -5.4 & 31.4 \\
\hline Booms, late 1990s & -5.2 & 7.2 & -15.1 \\
\hline
\end{tabular}

Source: AMECO and own calculations.

Figure 7, panel b, illustrates the divergence of fiscal behavior across countries. The standard deviation in the behavior of fiscal balances is relatively small during booms. However, as fiscal balances worsen rapidly during the downturn, divergence in responses increases. Growing concern about fiscal stability (and in some cases the approaching convergence deadline for joining EMU) induced more and more countries to bring their deficits under control as the bust continued. This suggests a regime shift from Keynesian demandsupporting policy during the early bust to a more stability- and confidence-oriented policy as the bust phase develops.

It could be argued, that boom-bust phases exacerbate deficit biases. This would happen, for example, if fiscal effects during large asset price cycles are much stronger than during periods of "normal” macro fluctuations and if the unexpected budgetary "relief" during booms is spent via expansionary tax cuts or spending increases. While expenditure and revenue policies will be examined in more detail in the next sub-section, there is evidence of differences in the effects of boom-bust regimes on fiscal balances.

The effects from output changes on fiscal balances are well documented in the automatic stabilizers-related literature (van den Noord, 2000; Bouthevillain et al 2001). However, more recently the effect of asset price changes on fiscal balances via wealth effects on consumption taxes, and capital turnover and capital gains/loss related tax windfalls has been analyzed. These effects can be rather significant, especially when the tax system is sensitive to asset prices and asset price changes are large and they come on top of regular cyclical influences on budgets (Eschenbach and Schuknecht, 2002a; OECD, 2003).

We provide two pieces of evidence that-indirectly and directly-support the claim of differential effects between boom-bust and normal regimes. First, the correlation between fiscal balances and asset prices is high and growing (Table 7). The correlation between the change in the fiscal balance and the change in real asset prices increased considerably and significantly than that with real output changes between the two periods 1971-1984 and 
Figure 7. Asset Price Cycles and Fiscal Variables

a. Fiscal balance
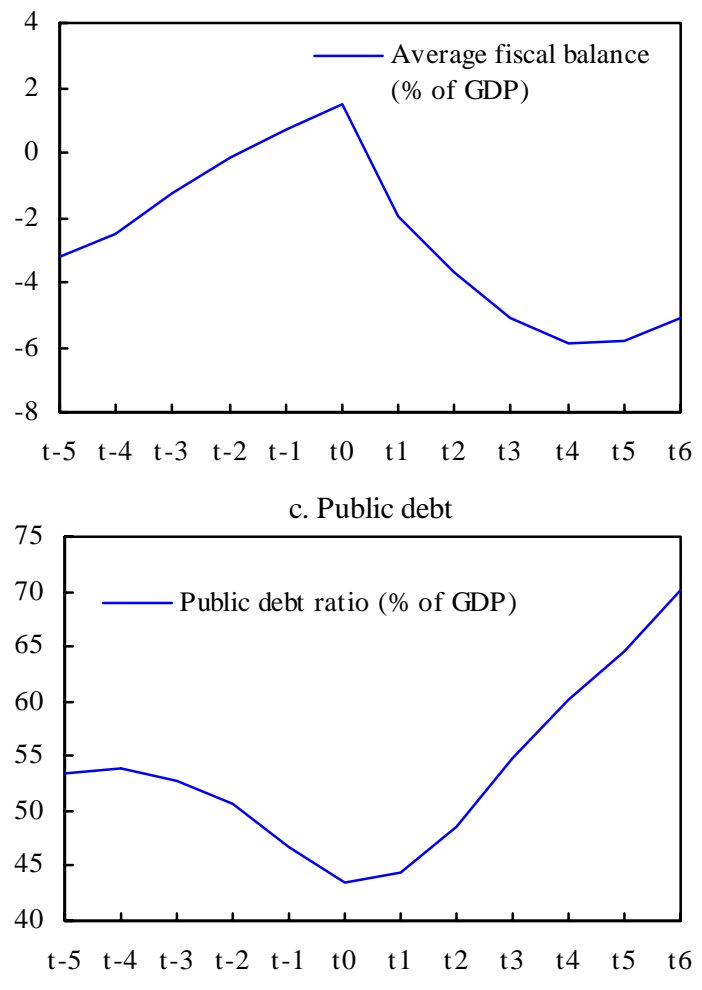

e. Real revenue growth
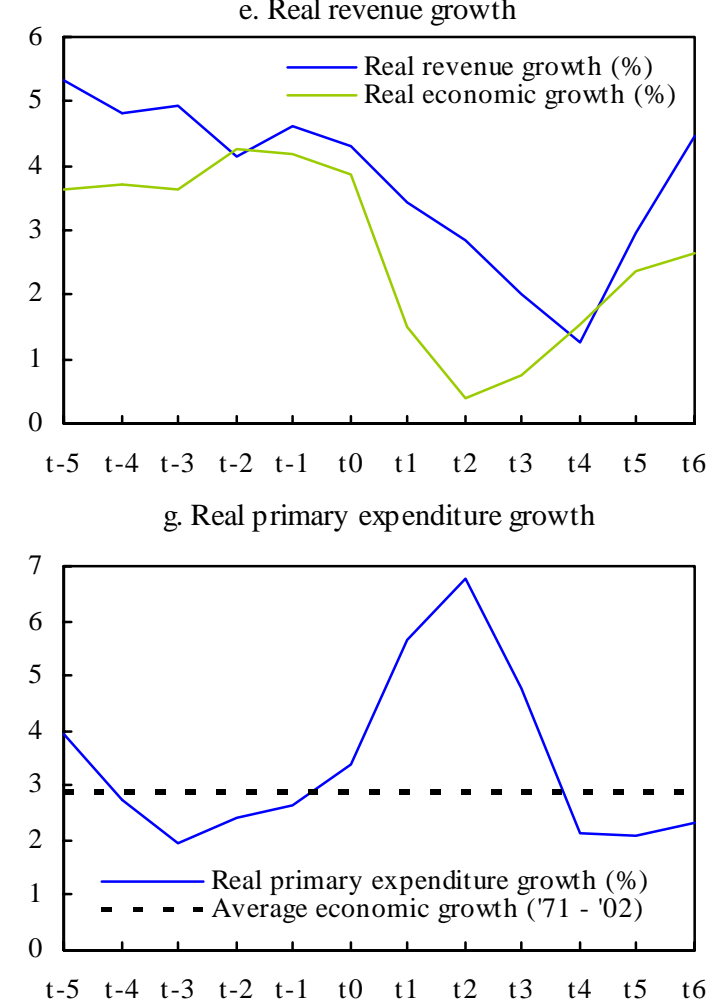

b: Average and variation of fiscal balance

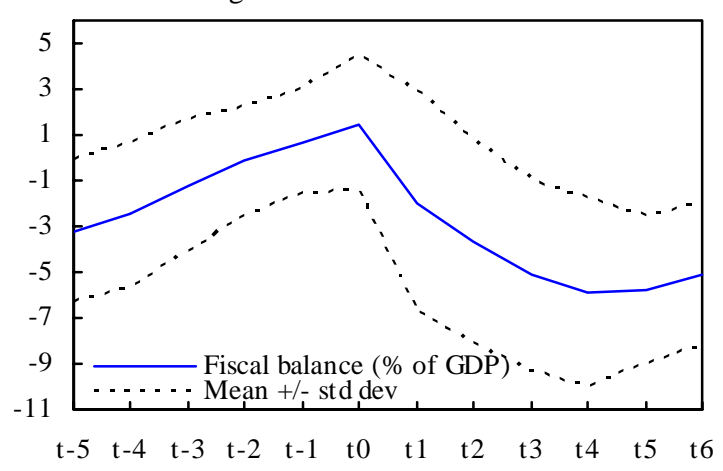

d. Average and variation of public debt ratio
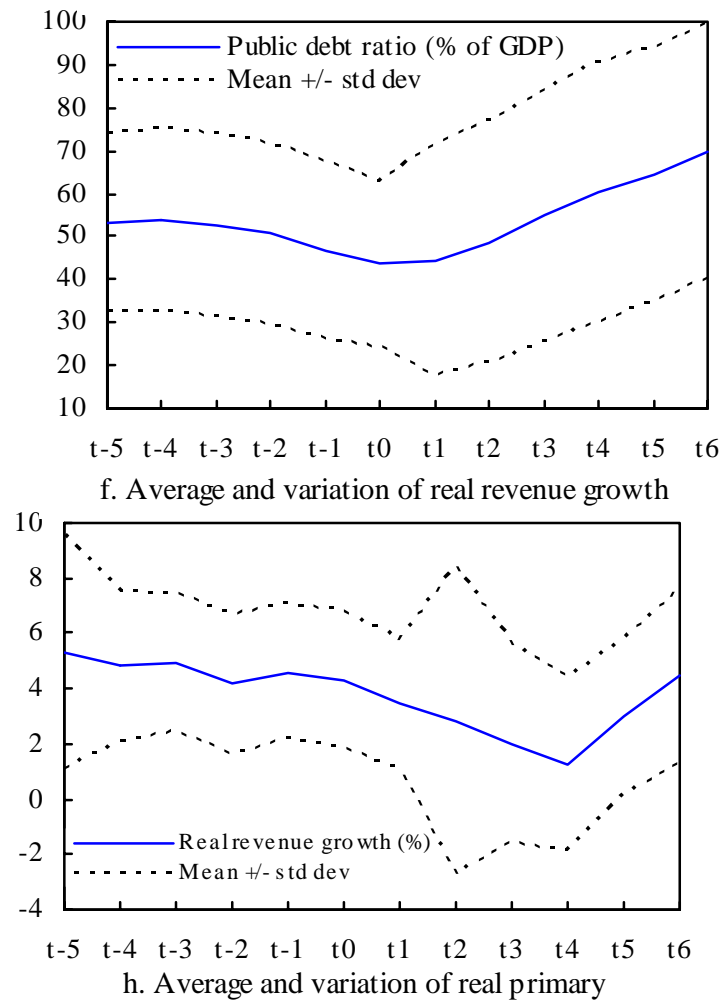

expenditure growth

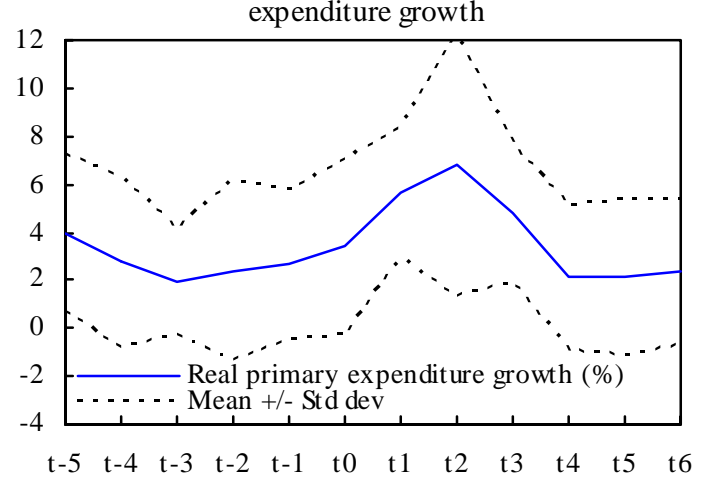

Source: AMECO and own calculations. 
Table 7: Correlation Between Fiscal Balances and Growth in Real Output and Asset Prices

\begin{tabular}{lrrrr}
\hline Fiscal balance/country & \multicolumn{2}{c}{$1971-1984$ 1/ } & \multicolumn{2}{c}{$1985-20021 /$} \\
\hline Correlation coefficients & $\begin{array}{r}\text { Change Fiscal Balance with: } \\
\text { Real Output } \\
\text { Growth }\end{array}$ & $\begin{array}{r}\text { Change Fiscal Balance with: } \\
\text { Price Growth }\end{array}$ & $\begin{array}{r}\text { Real Output } \\
\text { Growth }\end{array}$ & $\begin{array}{r}\text { Real Asset } \\
\text { Price Growth }\end{array}$ \\
\hline Australia & 0.70 & 0.57 & 0.81 & 0.56 \\
Belgium & 0.28 & 0.27 & 0.52 & 0.38 \\
Canada & 0.75 & 0.52 & 0.63 & 0.56 \\
Denmark & 0.70 & 0.65 & 0.62 & 0.52 \\
Finland & 0.39 & 0.19 & 0.89 & 0.81 \\
France & 0.49 & 0.57 & 0.58 & 0.53 \\
Germany & 0.61 & 0.33 & 0.10 & 0.54 \\
Ireland & 0.47 & 0.45 & 0.28 & 0.33 \\
Italy & 0.65 & 0.48 & 0.07 & 0.19 \\
Japan & 0.41 & 0.32 & 0.77 & 0.62 \\
Netherlands & 0.53 & 0.48 & 0.39 & 0.39 \\
Spain & 0.45 & 0.36 & 0.59 & 0.47 \\
Sweden & 0.30 & 0.38 & 0.35 & 0.72 \\
Switzerland & 0.09 & 0.05 & 0.35 & 0.47 \\
UK & -0.32 & -0.04 & 0.73 & 0.79 \\
US & 0.81 & 0.73 & 0.64 & 0.60 \\
& & & & \\
Average & 0.46 & 0.39 & 0.52 & 0.53 \\
\hline
\end{tabular}

Source: AMECO and own calculations.

1/ Maximum of contemporanous or 1-period lagged correlation.

1985-2002. Correlation coefficients are now roughly equal at $0.52 / 0.53$. Note also that the most marked deteriorations in fiscal balances fell into bust periods. Increasing leverage in the private sector, as mentioned above, and growing real estate and stock market valuations relative to GDP in the past two decades may have been contributing factors to this development.

Second, econometric analysis supports the claim of much stronger fiscal effects during strong asset price cycles. Given the significant differences across countries in tax regimes that suggest strongly differing coefficients across countries, and divergence in discretionary policy responses, we conduct a simple econometric analysis of the response of changes in fiscal balances to output growth during boom-bust phases and periods that do not qualify as boom bust episodes. The relevant regression equation is:

$$
\Delta \mathrm{b}_{\mathrm{t}}=\alpha+\left[\beta^{1}\left(\mathrm{I}^{1} \Delta \mathrm{y}_{\mathrm{t}}\right)+\gamma^{1}\left(\mathrm{I}^{1} \Delta \mathrm{y}_{\mathrm{t}-1}\right)\right]+\left[\beta^{0}\left(\mathrm{I}_{\mathrm{t}}^{0} \Delta \mathrm{y}_{\mathrm{t}}\right)+\gamma^{0}\left(\mathrm{I}_{\mathrm{t}}^{0} \Delta \mathrm{y}_{\mathrm{t}-1}\right)\right]+\varepsilon_{\mathrm{t}},
$$

where $\Delta b_{t}$ represents the change in the fiscal balance (as a percent of GDP), $\Delta y_{t}$ stands for real GDP growth, and $\varepsilon_{t}$ is a regression error. The indicator function $\mathrm{I}_{\mathrm{t}}{ }_{\mathrm{t}}$ takes a value of 1 during years where the economy was in a boom or bust year (as defined above) and 0 if the economy was in a "normal year;" the indicator function $\mathrm{I}^{0}{ }_{\mathrm{t}}$, by contrast, takes a value of 0 
during years where the economy was in a boom or bust year (as defined above) and 1 if the economy was in a "normal year." Thus, for example the estimated regression parameters $\beta^{1} / \gamma^{1}$ and $\beta^{0} / \gamma^{0}$ gauge the response of the fiscal balance to output growth in a boom-bust phase and outside boom-bust episodes, respectively. The difference between the regression parameters in the two regimes provides a useful measure of the differences in responsiveness of fiscal balances in the two regimes (without, however, specifying whether they reflect differential responses to output growth and/or the additional effect related to asset price changes).

The findings of these rather simple and broad-brush tests confirm our earlier hypotheses that boom-bust phases have a marked effect on fiscal balances. Table 8 provides the findings for all countries and estimations with contemporaneous and lagged coefficients. Averaged across countries, the results suggest that the responsiveness of the fiscal balance during boom-bust phases is almost double the responsiveness during "normal years."

Table 8: The Response of Fiscal Balances to Real GDP Growth During Asset Price Cycles, 1971-2002

\begin{tabular}{|c|c|c|c|c|c|}
\hline \multicolumn{6}{|c|}{ Dependent variable: Change in fiscal balance (in percent of GDP) } \\
\hline \multirow{2}{*}{ Estimated coefficients 1/ } & \multicolumn{3}{|c|}{ Boom-Bust Regime } & \multicolumn{2}{|c|}{ "Normal" Regime } \\
\hline & $\beta 1$ & $\gamma 1$ & & $\beta 0$ & $\gamma 0$ \\
\hline Australia & $0.55^{* *}$ & 0.09 & & $0.27 * *$ & $0.16^{* *}$ \\
\hline Belgium & $0.39 * *$ & -0.12 & & 0.13 & -0.21 \\
\hline Canada & $0.75 * *$ & -0.07 & & $0.37 * *$ & -0.06 \\
\hline Denmark & $0.76 * *$ & $0.50 *$ & & $0.50 * *$ & $0.23 *$ \\
\hline Finland & $0.71 * *$ & 0.01 & & 0.01 & $0.33 * *$ \\
\hline France & $0.32 *$ & 0.01 & & $0.48 * *$ & -0.22 \\
\hline Ireland & 0.12 & -0.15 & & -0.02 & -0.13 \\
\hline Italy & 0.32 & 0.01 & & $0.29 * *$ & -0.27 \\
\hline Japan & 0.18 & 0.18 & * & -0.03 & 0.22 \\
\hline Netherlands & $0.52 * *$ & -0.09 & & $0.33 * *$ & -0.01 \\
\hline Spain & $0.40 * *$ & -0.06 & & $0.21 *$ & -0.05 \\
\hline Sweden & $0.85 * *$ & 0.54 & * & 0.38 & 0.39 \\
\hline Switzerland & $0.53 * *$ & -0.44 & * & 0.05 & 0.09 \\
\hline United Kingdom & 0.24 & 0.29 & & -0.03 & 0.00 \\
\hline United States & $0.73^{* *}$ & 0.01 & & $0.47 * *$ & $0.17 *$ \\
\hline Average & 0.49 & 0.05 & & 0.23 & 0.04 \\
\hline
\end{tabular}

Memorandum item:

Estimation equation: $\quad \Delta \mathrm{b}_{\mathrm{t}}=\alpha+\left[\beta^{1}\left(\mathrm{I}_{\mathrm{t}}^{1} \Delta \mathrm{y}_{\mathrm{t}}\right)+\gamma^{1}\left(\mathrm{I}^{1}{ }_{\mathrm{t}} \Delta \mathrm{y}_{\mathrm{t}-1}\right)\right]+\left[\beta^{0}\left(\mathrm{I}^{0}{ }_{\mathrm{t}} \Delta \mathrm{y}_{\mathrm{t}}\right)+\gamma^{0}\left(\mathrm{I}_{\mathrm{t}}^{0} \Delta \mathrm{y}_{\mathrm{t}-1}\right)\right]+\varepsilon_{\mathrm{t}}$

Source: Own calculations.

$1 / * *(*)=$ significance at the $95(90)$ percent confidence level.

The difference in the estimated overall responsiveness $(0.27)$ is quite remarkable. Putting it into perspective with the findings of the previous section (cumulative output deviations during booms average 7 percent, while shortfalls during downturns average $81 \frac{1}{2}$ percent), the fiscal balance is boosted by roughly 2 percent on average during booms while being 
worsened by $2 \frac{1}{2}$ percent during busts, with these effects coming on top of the cyclical effects on budget balances during “normal” episodes.

The apparently high sensitivity of cyclical balances during boom-bust phases in asset prices could also shed light on an interesting recent finding by Gali and Perrotti (2003). They report that discretionary fiscal policy in EMU countries has become more countercyclical since the signing of the Maastricht Treaty in 1992. The finding is mainly based on estimates of the responsiveness of structural balances, as calculated and published by the OECD and therefore based on conventional estimates of the automatic cyclical responsiveness of budgets to cycles. When regressing these estimates of the structural balance on the output gap (and other variables), Gali and Perrotti (2003) find that structural balances generally tend to move more countercyclically after 1991 in EMU (as well as in most other industrial countries). They interpret the finding as suggesting a genuine improvement in the macroeconomic stabilization properties of fiscal policy.

However, if the prevalence of large-sized asset price swings increased during the 1990s, Gali's and Perrotti's (2003) finding could simply reflect the effect of underestimating the size of the automatic cyclical responsiveness of budgets during boom-bust phases in asset prices. The (OECD's) mis-measurement of structural balances would then be reflected in seemingly countercyclical movements in these structural balances relative to changes in the output gap. A casual comparison of the country-specific results reported in Gali and Perrotti (2003, Table 2) with this paper's classification of the timing of boom and bust phases in asset prices seems to be consistent with this interpretation.

As predicted and consistent with fiscal balance developments, public debt has been ratcheting up of debt over boom bust episodes (Table 6 and Figure 7, panel c). Average debt falls by less than 10 percent of GDP during booms but rises by almost 30 percent on average during busts. There is no marked difference between the busts of the 1970s and those of the early 1990s. But, consistent with the more favorable fiscal balance developments during recent booms, the behavior of debt during these episodes is also more positive: debt has been falling by an average of 15 percent of GDP during the upturns of the late 1990s. This decline in debt, however, is just about half of the debt increase during earlier busts.

Figure 7, panel d, provides some further information on the dispersion of debt ratios and debt developments. The standard deviation is very large from the outset and remains roughly constant during the boom. However, it increases during the bust, reflecting the rather uncomfortable stylized fact that debt increases rather more in countries that already start with a relatively high debt ratio. Countries with a low initial debt ratio are also better able to contain debt increases during the downturn. This also reflects stronger adverse effects from less favorable refinancing conditions in high debt countries.

\section{B. Revenue and Expenditure}

The stylized facts on revenue and expenditure suggest that boom-bust phases exacerbate existing spending and deficit biases. The fiscal revenue ratio rises both during booms and during busts as real revenue grows persistently above real GDP (Table 9 and Figure 7, panel e). This fact, however, masks very different underlying “stories”. During booms, 
Table 9: Boom-Bust Cycles and Revenue and Expenditure Trends

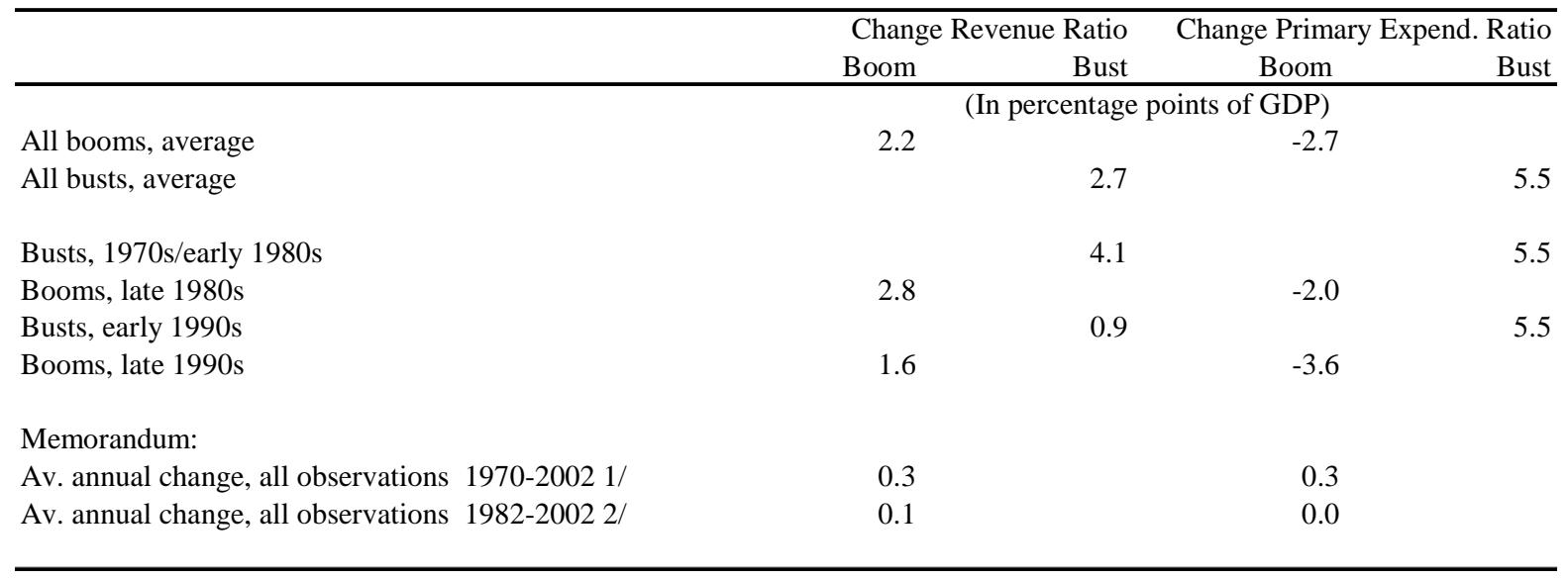

Source: AMECO and own calculations.

1 / This is consistent with the significant increase in the expenditure and revenue ratio in the 1970 s and the divergent trends thereafter.

$2 /$ The divergence in revenue and expenditure developments after the early 1980s reflects

budget consolidation that on average took place over the 20 year period.

existing evidence suggests that this is largely due to revenue windfalls. There have not been any significant tax increases during the late 1980s and 1990s booms that could serve as an alternative explanation, as documented in the country reports of international organizations. On the contrary, there has been an increasing tendency to use the good times for cutting taxes, starting out in the United States in the 1980s and spreading to continental Europe in the late 1990s.

As the bust set in, the behavior across countries initially differs markedly. Some countries let the automatic stabilizers and the reversal of revenue windfalls run its course and, thereby, accept low revenue growth for some time. Others quickly countervail the onset of growing deficits with tax increases (in some cases in the context of pre-EMU consolidation). This is reflected in the temporary increase in the standard deviation of revenue growth at the beginning of the bust (Figure 7, panel f). As the bust proceeds, revenue growth picks up again as taxes are frequently increased significantly.

Insufficiently restrictive public expenditure policies during booms and early phases of the bust are at the root of persistent average imbalances and growing spending ratios. Public spending is increasing by an average of 5.5 percentage points of GDP during bust phases while only half of this increase is reversed during booms (Table 9). Spending falls by only 2 percent of GDP in the boom of the late 1980s while it comes down by 3.6 percent in the second half of the 1990s, suggesting a trend toward more cautious expenditure policies. However, the fall is still smaller than the corresponding increase in the spending ratio during earlier busts.

Figure 7, panel g, shows that real public expenditure growth during booms remains close to the average growth rate of all sample countries over the past 30 years. While this reflects 
expenditure trends that are not very strongly expansionary in most countries, such expenditure growth in good times is proving not prudent enough to keep average expenditure growth over the full asset price cycle near trend output growth and to compensate for the strong increase in expenditure in the first three bust years (t1-t3). Moreover, expenditure growth is clearly on an upward trend as the boom proceeds. Recent booms show even less favorable dynamics towards the end of the upswing than the booms of the late 1980s.

As the bust unfolds, expenditure policies become strongly procyclical and spending growth briefly falls well below average growth. Comparing the integral below with that above the average growth line (and which is probably well above today's average trend growth across sample countries) is another way of illustrating the expansionary bias of expenditure policies over boom-bust episodes. The divergence increases briefly at the beginning of the downturn, largely reflecting some countries efforts to stimulate the economy in the late 1970s/1980s busts (Figure 7, panel h).

\section{Measurement of Underlying Fiscal Positions}

We also find support for our earlier claims that fiscal policymaking is complicated by measurement problems. Starting with the underlying fiscal position, an important concept that is frequently used to determine the need for fiscal consolidation in the near and medium term, there tends to be a measurement bias during the boom. The previous section already established that trend growth tends to be systematically overestimated during the boom and well into the bust before some underestimation sets in towards the end of the downturn.

This uncertainty about and measurement bias in the output gap can result in significant ex post revisions of the cyclically adjusted or structural balance. Table 10 illustrates this point for a number of EU countries by comparing 1999 structural balance estimates as provided in spring 2000 and in autumn 2003. Cyclically-adjusted balances have been revised downward by an average of almost 1 percentage point of GDP. In some cases, public finances were judged to be sound at the time while the same countries are now judged to have had significant underlying imbalances. The effect of these ex post revisions is clearly pro-cyclical: adjustment that should have taken place during the boom was not recognized due to measurement problems and then added to the adjustment Table 10: Revision of 1999 Cyclically Adjusted Balances, Selected EU Countries

\begin{tabular}{lrrr}
\hline Year & \multicolumn{3}{c}{1999} \\
\hline Forecast vintage & Spring 2000 & Autumn 2003 & Revision \\
\hline & (In percentage & points of GDP) & \\
Belgium & -0.3 & -1.1 & -0.8 \\
Denmark & 2.4 & 2.2 & -0.2 \\
Germany & -0.3 & -1.5 & -1.2 \\
Spain & -1.1 & -1.5 & -0.4 \\
France & -1.3 & -2.3 & -1.0 \\
Ireland & 0.8 & 1.0 & 0.2 \\
Italy & -1.3 & -1.9 & -0.6 \\
Netherlands & 0.7 & -1.3 & -2.0 \\
Finland & 1.9 & 0.6 & -1.3 \\
Sweden & 2.0 & 0.4 & -1.6 \\
United Kingdom & 1.4 & 0.8 & -0.6 \\
& & & \\
Average & 0.4 & -0.4 & -0.9 \\
Standard deviation & 1.4 & 1.5 & 0.6 \\
\hline
\end{tabular}

Source: Commission forecasts, spring 2000 and autumn 2003. 
An additional expansionary bias comes from the mismeasurement of the fiscal stance. Conventional analysis calculates this on the basis of deviations of output growth from trend and the elasticity of the fiscal balance to output changes. We found above that this elasticity is typically much larger during boom and bust periods than during "normal” times. The underestimation of the elasticity can help hide expansionary policies in the boom (by making the stance look more favorable) while overestimating discretionary expansion in the bust (as revenue shortfalls make the stance look less favorable).

A detailed examination of Sweden's fiscal balance developments helps illustrate this point. The structural balance in Sweden improved markedly between 1985 and 1989 before declining dramatically until 1993 according to commonly used databases (see Table 11). However, when carefully analyzing actual balance developments it becomes clear that other factors were much more important. In fact, discretionary fiscal policies were basically neutral until 1989. Moreover, they can only explain one quarter of the 12 percent structural balance deterioration between 1989 and 1993. Another quarter of the deterioration is each due to the regularization of Swedish commercial bank support in the 1991-93 budgets and due to asset price effects on fiscal balances. ${ }^{13}$

Table 11: Sweden's Fiscal Structural Balance Determinants, 1986-1993

\begin{tabular}{|c|c|c|c|c|c|c|c|c|c|}
\hline & 1985 & 1986 & 1987 & 1988 & 1989 & 1990 & 1991 & 1992 & 1993 \\
\hline 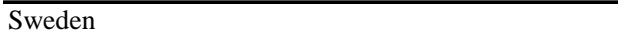 & \multicolumn{9}{|c|}{ (In percent of GDP) } \\
\hline Fiscal balance 1/ & -3.8 & -1.2 & 4.2 & 3.5 & 5.4 & 4.2 & -1.1 & -7.8 & -12.3 \\
\hline Cumulative change in fiscal balance $(1)=(2)+(3)$ & & 2.6 & 8.0 & 7.3 & 9.2 & 8.0 & 2.7 & -4.0 & -8.5 \\
\hline Cumulative cyclical influences (2) & & 0.8 & 2.4 & 3.2 & 4.1 & 4.1 & 1.9 & -2.8 & -1.6 \\
\hline Cumulative change in structural balance (3)=(sum4-7) & & 1.8 & 5.6 & 4.1 & 5.1 & 3.9 & 0.8 & -1.2 & -6.9 \\
\hline \multicolumn{10}{|l|}{ Of which: $2 /$} \\
\hline Effect of discretionary revenue measures (4) & & -0.3 & -0.1 & -0.2 & 0.1 & -0.4 & -3.1 & -3.9 & -3.1 \\
\hline Effect of asset prices (5) & & 1.3 & 1.7 & 2.7 & 1.8 & 1.5 & 0.4 & -1.5 & -1.4 \\
\hline Bank support (6) & & 0.0 & 0.0 & 0.0 & 0.0 & 0.0 & -0.3 & -0.8 & -2.9 \\
\hline Residual (7) & & 0.7 & 4.0 & 1.7 & 3.2 & 2.8 & 3.8 & 5.0 & 0.5 \\
\hline
\end{tabular}

Source: WEO and Eschenbach and Schuknecht, 2002b.

1/ WEO database, reference year for all following lines is 1985.

A final challenge arises from the uncertainty about the length and depth of the boom and the downturn. If during a bust the significant automatic effects from the asset price downturn on fiscal balances are compounded by pressures to engage in expansionary policies, this could give rise to risks of setting in motion fiscal trends that are viewed as unsustainable, a perception that could in turn weigh on private sector confidence. This issue is most likely to arise if policymakers did not build up a comfortable fiscal surplus position during the boom period and respond to the downturn with activist fiscal policies that do little to speed up the resolution of the private sector's balance sheet problems (which then, in turn, prolong the downturn and its adverse fiscal effects).

${ }^{13}$ See the detailed case studies underlying this data as conducted by Eschenbach and Schuknecht, 2002b. 


\section{Lessons for Fiscal Policy}

From the review of stylized facts in the previous section, we draw several prescriptive lessons for fiscal policy behavior during boom-bust phases in asset prices.

\section{Lessons for Short-Term Fiscal Policy Behavior}

- $\quad$ Fiscal policymakers should guard against misreading “revenue surprises” during asset price boom periods as durable improvements in the underlying budget position, and vice versa during bust periods. Put differently, the effects of automatic fiscal stabilizers are large during boom-bust phases (and larger than measured by the differences between actual balances and conventional measures of "structural budget balances”). This suggests using care when interpreting mechanically derived changes in the structural balance. Moreover, this implies that policymakers should be willing to accept considerable "excess volatility” in revenue and balances during boom-bust phases in asset prices to avoid a procyclical stance.

- $\quad$ The difficulty to assess trend growth and output gap not only makes the calculation of the structural balance hazardous but it also blurs the distinction between automatic stabilizers and discretionary policies. If trend growth is overestimated ex ante, the operation of automatic stabilizers looks like expansionary policies ex post when trend growth/output gaps have been reassessed. In other words, prudent trend-growth estimates (and their timely correction in case of misestimation) are the best way to sustain the operation of automatic stabilizers even during prolonged bust phases without incurring destabilizing fiscal imbalances.

- $\quad$ The case against countercyclical policy during contractions driven by asset price cycles could be less clear-cut than usually presented. However, one might also argue that spending dynamics should be adapted in a discretionary and pro-cyclical manner as the persistence and turning point of high- and low-growth phases is hard to predict. Moreover, the effectiveness of typical expansionary Keynesian policies may be limited if persistent slow growth is driven by balance sheet repair efforts and if rising imbalances undermine expectations of macroeconomic stability. ${ }^{14}$ In countries with large backlogs of structural reforms, implementing these reforms during a prolonged bust phase may in fact be a way of shortcutting the duration of the balance sheet repair phase if reforms improve expectations of longer-term growth prospects. By the same token, some fiscal measures aimed at consolidating a deteriorating fiscal

\footnotetext{
${ }^{14}$ See Jaeger (2003) for a discussion of the role of corporate balance sheet adjustments in explaining protracted slow growth in the euro area.
} 
position, for example raising the tax burden of the corporate sector, may aggravate balance sheet adjustment pressures. ${ }^{15}$

- $\quad$ Fiscal institutions and rules that impart a strong procyclical bent to fiscal policyessentially balanced-budget rules_-can be particularly costly during large asset price cycles. The implied procyclical bent of fiscal policy during the boom period may add additional momentum to the boom, while the implied procyclical need to raise taxes and cut spending during the bust phase may further sap demand and confidence.

- $\quad$ Finally, fiscal rules that are in principle designed to preserve the operation of automatic stabilizers (such as the Stability and Growth Pact (SGP)) by requiring policy makers to aim at an underlying balance that is at sufficient distance from an upper fiscal limit (such as the SGP's 3 percent deficit limit) are more appropriate than balanced budget rules. But nevertheless, they are not impervious to the challenges of boom-bust episodes. First, if policy makers mistake positive "revenue surprises" during the boom as improvements in the underlying fiscal position or fiscal institutions have a procyclical bias, the fiscal position at the end of the boom will be much weaker than warranted. Second, during the bust phase, the upper limit may be too tight owing to "excess variability" of the balance as well as the potentially protracted contraction following an asset price boom. This issue could be of particular importance for countries striving to enter EMU, which could experience particularly pronounced asset price booms in the run up to entry as they are likely to benefit from the convergence of nominal interest rates and a boom in capital inflows.

\section{Lessons for Long-Term Fiscal Policy Behavior}

- While policy makers may need to permit greater variability in fiscal balances they also need to secure sound fiscal positions on average over the cycle so as to prevent a ratcheting up of the debt ratio over time. This would typically require significant surpluses during booms. It would also require more favorable fiscal positions to secure an adequate pace of debt reduction in high-debt countries. This should create a sufficient safety margin to accommodate major debt increases during a bust phase, which could otherwise raise concerns about fiscal sustainability. ${ }^{16}$

- $\quad$ Fiscal policymakers should also guard against unsustainable expenditure dynamics and pursue cautious expenditure growth especially when budget constraints seem to soften as the boom proceeds and when demand falters as the bust sets in. Otherwise, the ensuing upward bias in expenditure ratios would work against structural policy

${ }^{15}$ See Giammarioli and Schuknecht (2003) for analysis and examples. Of course, the design of fiscal measures is key so as to prevent moral hazard due to the expectation of some form of government bailout.

${ }^{16}$ Fiscal rules that support both short-term stabilization within deficit limits and long term sustainability via debt constraints have been examined by Marín (2002). 
objectives of stable or falling tax and debt ratios. Given political economy incentives due to politicians' time horizon typically being much shorter than an asset price cycle, there is a strong argument for effective expenditure rules that contain real expenditure growth at or below long term trend growth.

- Determined structural expenditure reductions during booms may help contain the unsustainable and mutually reinforcing upward dynamics of demand and asset prices while also supporting sustainable public finances and higher growth. However, the demand, balance sheet, and growth implications and their complex interaction should be carefully assessed to prevent major untimely and unwarranted side effects.

\section{Conclusions}

Boom-bust phases in asset prices have become an increasingly pervasive feature of macroeconomic developments in industrial countries. In fact, many industrial countries ended the last century at the peak of an unusually large-sized equity bubble. Many of these countries' fiscal policy behavior during the boom as well as during its aftermath has raised serious questions about countries' commitment to previously announced fiscal rules and the sustainability of their medium-term fiscal outlook.

The paper argued that boom-bust phases in asset prices pose several novel challenges to fiscal policymakers. First, expansions and contractions in economic activity are unusually persistent, turning points are hard to forecast, and the nature of output fluctuations (particularly the size of output gaps) is difficult to assess. Thus, boom-bust phases in asset prices can create an inhospitable macroeconomic environment for budget planning and execution, particularly to the extent that forecasters and analysts adopt a "business as usual" attitude that envisages output growth reverting to its mean quickly. Second, conventional estimates of revenue elasticities tend to underestimate the actual response of fiscal revenue to output during boom-bust phases-implying a potential for spurious assessments of the strength of underlying fiscal positions during booms. And third, boom-bust cycles in asset prices tend to exacerbate the consequences of already existing procyclical biases in fiscal policy behavior (mainly stemming from balanced budget rules at lower government levels and PAYG rules for financing social security systems) as well as political economy biases toward higher spending ratios and debt-raising the macroeconomic cost of fiscal rules that limit the flexibility of short-term deficit fluctuations as well as the cost of fiscal institutions that promote the expansion of the size of government.

The findings of this paper support an already existing trend toward adopting fiscal policy rules that secure a sound medium-term orientation of fiscal policies while leaving adequate short-term fiscal flexibility. The accumulated evidence also seems to suggest that the success of such fiscal policy rules largely hinges on credibly containing expenditure growth and preventing tax cuts during the "high temptation phases" toward the end of a prolonged boom and at the onset of bust phases in asset prices. Moreover, anticyclical fiscal policy actions during bust phases would have to be more tuned toward helping balance sheet repair efforts in the aftermath of burst asset price bubbles rather than seeking to pump-prime aggregate demand. 
This paper is only a first effort toward assembling the stylized facts that characterize fiscal developments and policy behavior during asset price booms and busts and drawing normative conclusions for policy. At a minimum, the paper seems to show that much more work is needed in this area, particularly on the role of tax and expenditure policies in affecting asset price boom-bust phases and on the design of appropriate fiscal policy rules. 


\section{References}

Bernanke, Ben, Mark Gertler and Simon Gilchrist, 1999, “The Financial Accelerator in a Quantitative Business Cycle Framework,” in Handbook of Macroeconomics, Vol. 1, ed. by J.B.Taylor, and M. Woodford (Amsterdam: North Holland).

Bordo, Michael, and Olivier Jeanne, 2002, "Boom-Busts in Asset Prices, Economic Instability, and Monetary Policy,” NBER Working Paper 8966 (Cambridge, Massachusetts: MIT Press).

Borio, C.E.V., N. Kennedy, and S.D. Prowse, 1994, “Exploring Aggregate Asset Price Fluctuations Across Countries: Measurement, Determinants, and Monetary Policy Implications,” BIS Economic Papers, No. 40 (Basel: Bank for International Settlements).

Borio, Claudio, and Philip Lowe, 2002, “Asset Prices, Financial and Monetary Stability: Exploring the Nexus,” BIS Working Paper, No. 114 (Basel: Bank for International Settlements).

Borio, Claudio, William English, and Andrew Filardo, 2003, “A Tale of Two Perspectives: Old or New Challenges for Monetary Policy?,” BIS Working Paper, No. 127 (Basel: Bank for International Settlements).

Bouthevillain, C., and others, 2001, “Cyclically Adjusted Budget Balances: An Alternative Approach,” ECB Working Paper 77 (Frankfurt: European Central Bank).

Briotti, Gabriella, 2004, “Consolidation Experiences in EU Countries,” ECB Occasional Paper, forthcoming ((Frankfurt: European Central Bank).

Buti, Marco, Sylvester Eijffinger, and Daniele Franco, 2003, "Revisiting the Stability and Growth Pact: Grand Design or Internal Adjustment,” CEPR Discussion Papers 3692 (London: Centre for Economic Policy Research).

Collyns, Charles, and G. Russell Kincaid (eds.), 2003, Managing Financial Crises: Recent Experience and Lessons for Latin America, IMF Occasional Paper 217 (Washington: International Monetary Fund).

Detken, Carsten, and Frank Smets, 2003, “Asset Price Booms and Monetary Policy,” (unpublished; Frankfurt: European Central Bank).

Eschenbach, Felix, and Ludger Schuknecht, 2002a, “Asset Prices and Fiscal Balances, ECB Working Paper 141 (Frankfurt: European Central Bank).

_ _ 2002b,“The Fiscal Costs of Financial Instability Revisited,” ECB Working Paper 191 (Frankfurt: European Central Bank). 
Fatas, Antonio, and others, 2003, "Stability and Growth in Europe: Towards a Better Pact," Monitoring European Integration 13 (London: Centre for Economic Policy Research).

Gaimmarioli, Nicola and Ludger Schuknecht, 2003, “The Fiscal Financial Transmission Channel: Conceptual and Practical Issues,” (unpublished; Frankfurt: European Central Bank).

Gali, Jordi, and Roberto Perotti, 2003, "Fiscal Policy and Monetary Integration in Europe,” NBER Working Paper 9773 (Cambridge, Massachusetts: MIT Press).

Harding, Don, and Adrian Pagan, 2002, "Dissecting the Cycle: A Methodological Investigation,” Journal of Monetary Economics, Vol. 49, pp. 365-81.

Hemming, Richard, Michael Kell, and Axel Schimmelpfennig, 2003, Fiscal Vulnerability and Financial Crises in Emerging Market Economies, IMF Occasional Paper No. 218 (Washington: International Monetary Fund).

Honahon, Patrick, and Daniela Klingebiel, 2003, “The Fiscal Cost Implications of an Accommodating Approach to Banking Crises,” Journal of Banking and Finance, Vol. 27, pp. 1539-1560.

International Monetary Fund, 2000, World Economic Outlook, May 2000 (Washington: International Monetary Fund).

—_, 2003, World Economic Outlook, April 2003 (Washington: International Monetary Fund).

—_, 2003, "Deflation: Determinants, Risks, and Policy Options_Findings of an Interdepartmental Task Force” (Washington: International Monetary Fund).

Jaeger, Albert, 2003, “Corporate Balance Sheet Restructuring and Investment in the Euro Area,” IMF Working Paper No. 03/117 (Washington: International Monetary Fund).

Manasse, Paolo, Nouriel Roubini, and Axel Schimmelpfennig, 2003, "Predicting Sovereign Debt Crisis,” (unpublished; Washington: International Monetary Fund).

Marín, Jose, 2002, “Sustainability of Public Finances and Automatic Stabilisation Under A Rule of Budgetary Discipline,” ECB Working Paper 193 (Frankfurt: European Central Bank).

OECD, 2003, “Re-Assessing Cyclically-Adjusted Balances,” Economic Outlook No. 73, pp. 24-25 (Paris: Organisation for Economic Co-operation and Development). 
Van den Noord, Paul, 2000, "The Size and Role of Automatic Fiscal Stabilizers in the 1990s and Beyond,” OECD Economics Department Working Paper No. 230 (Paris: Organisation for Economic Co-operation and Development).

Zarnowitz, Victor, 1985, "Recent Work on Business Cycles in Historical Perspective," Journal of Economic Literature, Volume 23, pp. 523-80. 